\title{
Regulatory MicroRNAs in T2DM and Breast Cancer
}

\author{
Ilhaam Ayaz Durrani (D, Attya Bhatti * (D) and Peter John \\ Department of Healthcare Biotechnology, Atta-ur-Rehman School of Applied Biosciences (ASAB), \\ National University of Sciences and Technology (NUST), H-12, Islamabad 44000, Pakistan; \\ ilhaam.ayaz.durrani@gmail.com (I.A.D.); pjohn@asab.nust.edu.pk (P.J.) \\ * Correspondence: attyabhatti@gmail.com
}

\section{check for}

updates

Citation: Durrani, I.A.; Bhatti, A.; John, P. Regulatory MicroRNAs in T2DM and Breast Cancer. Processes 2021, 9, 819. https://doi.org/ $10.3390 /$ pr9050819

Academic Editor: Jong Kook Park

Received: 30 January 2021

Accepted: 27 February 2021

Published: 8 May 2021

Publisher's Note: MDPI stays neutral with regard to jurisdictional claims in published maps and institutional affiliations.

Copyright: (c) 2021 by the authors. Licensee MDPI, Basel, Switzerland. This article is an open access article distributed under the terms and conditions of the Creative Commons Attribution (CC BY) license (https:// creativecommons.org/licenses/by/ $4.0 /)$.

\begin{abstract}
MicroRNAs orchestrate the tight regulation of numerous cellular processes and the deregulation in their activities has been implicated in many diseases, including diabetes and cancer. There is an increasing amount of epidemiological evidence associating diabetes, particularly type 2 diabetes mellitus, to an elevated risk of various cancer types, including breast cancer. However, little is yet known about the underlying molecular mechanisms and even less about the role miRNAs play in driving the tumorigenic potential of the cell signaling underlying diabetes pathogenesis. This article reviews the role of miRNA in bridging the diabetes-breast cancer association by discussing specific miRNAs that are implicated in diabetes and breast cancer and highlighting the overlap between the disease-specific regulatory miRNA networks to identify a 20-miRNA signature that is common to both diseases. Potential therapeutic targeting of these molecular players may help to alleviate the socioeconomic burden on public health that is imposed by the type 2 diabetes mellitus (T2DM)-breast cancer association.
\end{abstract}

Keywords: microRNA; miRNA; T2DM; breast cancer; diabetes-breast cancer association

\section{Introduction}

MicroRNAs, being integral to the central dogma of life as we know it at the molecular level, orchestrate the tight regulation of cellular mechanisms, such as gene transcription, translation, RNA interference, DNA repair, and even cell-cell communication [1-3]. Also known as miRNA, these short strands of RNA, about 19-25 nucleotides long, are a subclass of endogenous small noncoding RNA molecules [4]. Unlike the coding RNA, which transcribes hereditary information from DNA and translates it into a protein, a miRNA is not translated into an amino acid primary sequence; instead, its functional significance is identified by the regulatory niche it serves for various cellular and biological functions.

miRNAs exist as antisense single strands to target genes, negatively regulating their expression post transcription. Genes encoding miRNA are transcribed into primary transcripts (pri-miRNA), which are several kilobases in length, by the enzymatic activity of RNA polymerase II within the nucleus, and which are then subjected to capping and polyadenylation, as depicted in Figure $1[5,6]$. These pri-miRNAs are shortened to form precursor miRNA molecules (pre-miRNA) by the action of Drosha, an enzyme belonging to the RNA polymerase III family, in a complex with DCGR8/Pasha and then exported to cytoplasm via exportin-5. Further cleavage by Dicer, another RNA polymerase III enzyme, and degradation of the complementary strand generates shorter single-stranded RNA molecules, referred to as mature miRNA [7]. The final form, as part of the RNA-induced gene silencing complex (RISC), binds to its complementary mRNA sequence and targets it for degradation or negative regulation at the protein translation level [8]. Hence, miRNAs serve as a critical component for transcriptional gene silencing.

Within the mature miRNA's structure, the $5^{\prime}$ end constituting the "miRNA seed" displays evolutionary conservation in its sequence and has been studied for miRNA target recognition [9]. It is also crucial for mature miRNA's stability, as well as its recruitment 
within the miRNA-RISC (miRISC) complex [10-14]. With the seed sequence being only six nucleotides long, each miRNA is believed to regulate multiple genes [15]. The entire biogenesis process is regulated in a spatiotemporal manner, following which, miRNAs are found to be present in all main cellular compartments and bodily fluids, implying the diversity in their biological role.

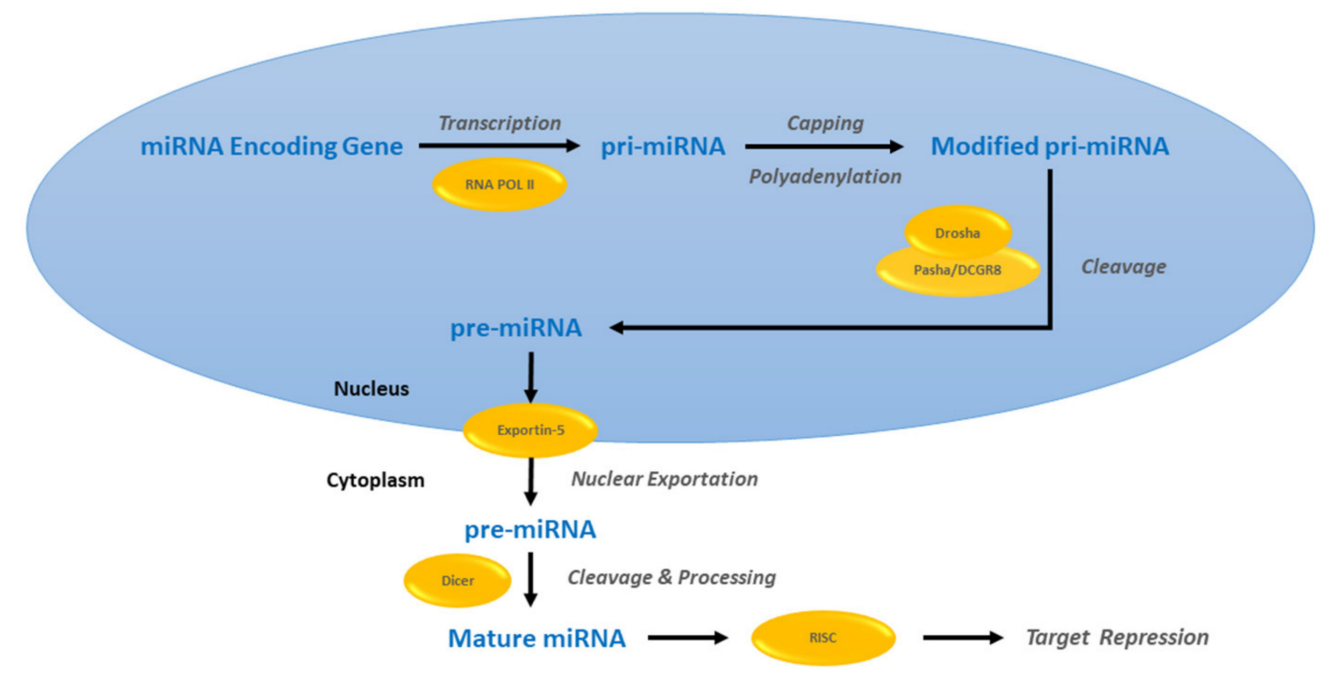

Figure 1. MicroRNA (miRNA) biogenesis and target gene repression. A miRNA encoding gene is transcribed into a primary miRNA (pri-miRNA), which undergoes subsequent post-transcriptional modification and then cleavage to generate a precursor miRNA (pre-miRNA). These pre-miRNA molecules are exported out of the nucleus and further cleaved and processed to their final form, mature miRNAs.

Hence, specific miRNA dysregulations may impose detrimental consequences on gene regulation and subsequent disease development [16]. The role of miRNA in various complex pathological conditions, such as diabetes, cardiovascular conditions, autoimmune disorders, and human cancers, including breast cancer, has been well established [17-21]. Diabetes and cancer, which are two polygenic and multifactorial diseases, exercise a significant overlap in cell signaling pathways and their dysregulations [22-24]. This lays a solid molecular base for a diabetes-cancer association, which is a subject of focus for numerous studies to date, as diabetes-induced carcinogenesis becomes an increasingly common phenomenon $[25,26]$.

There is an increasing amount of epidemiological evidence associating diabetes, particularly type 2 diabetes mellitus (T2DM), which is the most prevalent type of diabetes, to an elevated risk of cancers of various tissue origins. However, not all cancers associate equally. Diabetic patients have shown a greater increased risk for liver, pancreatic, and endometrium cancers as compared to cancers of the breast, colon-rectum, and bladder, all of which reportedly associate positively with T2DM [27-32]. Furthermore, prostate cancer has shown a negative association and lung cancer has depicted no association with T2DM $[33,34]$. With diabetes and cancer already emerging as two leading causes of death, an association between the two only aggravates the socioeconomic burden on global public health, and hence, needs to be addressed [35].

Unfortunately, beyond the epidemiological basis, the underlying molecular mechanisms mediating the diabetes-cancer association are not fully understood. So far, hyperglycemia, hyperinsulinemia, insulin resistance, oxidative stress, inflammation, and hormonal imbalances, which are all characteristic of T2DM, have been employed as potential molecular bases underlying this association [36-38]; however, the role of miRNA-mediated dysregulations in modulating these features and their tumorigenesis-driving potential in diabetic patients is still underexplored. 
In this context, miRNAs are crucial cellular regulatory factors; as such, this review focuses on highlighting their significance in mediating the diabetes-breast cancer crosstalk that leads to breast-cancer-induced T2DM onset and specifically T2DM-induced breast cancer. By discussing the roles of specific miRNAs in both T2DM and breast cancer individually and then interpreting the overlap between disease-specific regulatory miRNA networks, this paper identifies a conserved miRNA signature that is common to both diseases. Further molecular studies investigating these miRNAs may potentiate their role as biomarkers with diagnostic, prognostic, and therapeutic significance for diabetes and breast cancer patients.

\section{Article Selection for the Literature Review}

For this literature review, the online database PubMed was searched through using the keywords "T2DM" (OR "diabetes") AND "breast cancer" (OR "cancer") AND "microRNA" (OR "miRNA") and "T2DM" (OR "diabetes") OR "breast cancer" (OR "cancer") AND "microRNA" (OR "miRNA") in the given combinations and separately. Original articles published on both in vitro and in vivo experimental results were retrieved. Review articles were also studied to extract second references for original articles that were relevant to the research topic. A total of 301 articles were extracted for T2DM and over 6000 for breast cancer for the period 2011-2021. In view of the extensive literature available, further shortlisting was done to include studies based on miRNA's implication in either disease, yet targeting a pathway common to both diabetes and breast cancer. Hence, around 170 articles were summarized in this review and utilized for Venn diagram analysis.

\section{The Role of miRNAs in T2DM}

The functional roles of many miRNAs have been established in T2DM with numerous studies implicating miRNA dysregulation in diverse aspects of T2DM pathogenesis. These include beta-cell function, islet development, adipocyte and beta-cell differentiation, insulin production and its secretion, insulin resistance, glucose homeostasis, lipid metabolism, and diabetic treatment $[39,40]$. For instance, miR-148b, miR-223, miR-126, miR-19a, and miR-130a have all been identified as diagnostic biomarkers for T2DM [41,42], while miR126, which has been shown to positively correlate with impaired glucose tolerance, has been identified as a prognostic marker for T2DM. Furthermore, miR-182-5p and potentially miR-30a-5p may be pursued as diagnostic markers for T2DM [43]. miR-375 has also been reported as a novel biomarker as its upregulated plasma levels correlate with the T2DM phenotype [44].

Additionally, Karolina et al. reported a signature of 4 miRNAs, namely, miR-142, mi146a, miR-150, and miR-182, which could differentiate between impaired fasting glucose (IFG) and T2DM, besides the miR-29a, miR-192, and miR-320 reported previously. Other miRNAs differentially expressed for T2DM include miR-21, miR-30d, miR-148a-3p, miR146b, miR-148a-3p, miR-147, and miR-486 (upregulated) and let-7b-5p, miR-1-3p, miR-2223p, miR-186, miR-23a, and miR-126 (downregulated) [45-48].

Hence, a vast number of miRNAs have been implicated in diabetes pathology so far and this section classifies these miRNAs based on their functional significance in T2DM, the summary of which is listed in Table 1, along with their target genes or implicated pathways. 
Table 1. miRNA expression and target gene regulation in type 2 diabetes mellitus (T2DM).

\begin{tabular}{|c|c|c|c|c|}
\hline T2DM Characteristic & miRNA & Expression & Target mRNA/Implicated Pathway & Reference \\
\hline \multirow{15}{*}{ Beta-cell function } & miR-143 & $\uparrow$ & ORP8/insulin-AKT pathway & [49] \\
\hline & miR-144 & $\uparrow$ & IRS1 & [50] \\
\hline & miR-30d & $\uparrow$ & Cyclin E2, RUNX2, PI3K/insulin pathway & {$[51-54]$} \\
\hline & $\operatorname{miR}-126$ & $\uparrow$ & IRS1 & [55] \\
\hline & miR-146a & $\uparrow$ & $N F-\kappa B$ & {$[56]$} \\
\hline & miR-375 & $\uparrow$ & ERK1/2, Mtpn & {$[57,58]$} \\
\hline & miR-21 & $\downarrow$ & PTEN/PI3K-AKT pathway, TGF- $\beta 1 / S M A D 3$ pathway & {$[54,59]$} \\
\hline & $\mathrm{miR}-24$ & $\uparrow$ & $M A P K, P 38$ & {$[60]$} \\
\hline & miR-34a & $\uparrow$ & VAMP2 & [61] \\
\hline & miR-96 & $\uparrow$ & FoxO1, SOX6 & [62] \\
\hline & miR-199a-5p & $\uparrow$ & SIRT1 & [63] \\
\hline & $\operatorname{miR}-125 b-5 p$ & $\uparrow$ & Inhibits JNK pathway & {$[64]$} \\
\hline & $\operatorname{miR}-9$ & $\uparrow$ & SYTL4 & {$[65,66]$} \\
\hline & $\operatorname{miR}-124 a$ & $\uparrow$ & Mtpn, FoxA2, Rab27A & [67-69] \\
\hline & miR-15 & $\uparrow$ & - & [70] \\
\hline \multirow{8}{*}{ Insulin resistance } & miR-27a & $\uparrow$ & PPAR $\gamma$ & [71] \\
\hline & miR-221 & $\uparrow$ & Impairs the PI3K/AKT pathway & [72] \\
\hline & miR-382-3p & $\uparrow$ & Resistin & [73] \\
\hline & $\mathrm{miR}-223$ & $\uparrow$ & GLUT4 & [74] \\
\hline & miR-128-3p & $\uparrow$ & ISL1-dependent Wnt pathway & [75] \\
\hline & miR-145 & $\uparrow$ & Insulin-AKT pathway & [54] \\
\hline & miR-155 & $\downarrow$ & HDAC4 & [76] \\
\hline & miR-18a & $\downarrow$ & PTEN & {$[77,78]$} \\
\hline \multirow{6}{*}{ Metabolism } & miR-194 & $\downarrow$ & PI3K/AKT pathway & [79] \\
\hline & miR-146b & $\uparrow$ & IRS1, GLUT4 & [80] \\
\hline & miR-182 & $\downarrow$ & FoxO1, PDK4 & [81] \\
\hline & miR-222 & $\uparrow$ & GLUT4 & {$[54,82,83]$} \\
\hline & miR-125a-5p & $\uparrow$ & STAT3 & [84] \\
\hline & $\mathrm{miR}-33 \mathrm{a} / \mathrm{b}$ & $\uparrow$ & 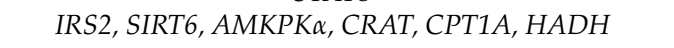 & [85] \\
\hline \multirow{7}{*}{$\begin{array}{l}\text { Oxidative stress/ } \\
\text { inflammation }\end{array}$} & miR-146a & $\uparrow$ & $N F-\kappa B$ & [56] \\
\hline & miR-424 & $\uparrow$ & Activates KEAP1 and NRF2 & {$[86]$} \\
\hline & $\mathrm{miR}-181 \mathrm{~b} / \mathrm{miR}-126-5 \mathrm{p}$ & $\downarrow$ & $N F-\kappa B$ & {$[87]$} \\
\hline & miR-21 & $\downarrow$ & PDCD4, Pclo & [88] \\
\hline & miR-223 & $\downarrow$ & KEAP1 & [89] \\
\hline & miR-199a-5p & $\begin{array}{r}r \\
\uparrow\end{array}$ & SIRT1 & [63] \\
\hline & $\mathrm{miR}-126-3 p$ & $\downarrow$ & $V C A M-1$ & [90] \\
\hline \multirow{8}{*}{$\begin{array}{l}\text { Clinicopathological } \\
\text { features }\end{array}$} & miR-496 & $\downarrow$ & $m T O R$ upregulation & [91] \\
\hline & miR-486-3p & $\uparrow$ & $T^{2}-$ & [92] \\
\hline & $\operatorname{miR}-423$ & $\downarrow$ & - & [92] \\
\hline & miR-28-3p & $\uparrow$ & IGF1, IGF2R, MAPK1, MAP2K3, RAF1 & [93] \\
\hline & miR-146a-5p & $\downarrow$ & SMAD4, TRAF6, IRAK1 & [94] \\
\hline & miR-16-2-3p & $\uparrow$ & - & [92] \\
\hline & miR-1-3p & $\downarrow$ & KCNQ1 tv1 & [95] \\
\hline & $\begin{array}{l}\text { miR-23a/ } \\
\text { miR-186 }\end{array}$ & $\downarrow$ & - & [48] \\
\hline \multirow{9}{*}{ Diabetic complications } & miR-4463 & $\uparrow$ & Activates $P I 3 K / A K T$ pathway & [96] \\
\hline & miR-196-3p & $\uparrow$ & - & [97] \\
\hline & miR-203-3p & $\uparrow$ & SMAD1 & [98] \\
\hline & miR-20b-5p & $\uparrow$ & Regulates $W n t 9 b / \beta$-cell signaling & [99] \\
\hline & $\operatorname{miR}-423$ & $\downarrow$ & VEGF signaling & [100] \\
\hline & miR-21 & $\uparrow$ & PPAR $\alpha$ & {$[101,102]$} \\
\hline & let-7b-5p & $\downarrow$ & IRS1/Mt.Cytb up-regulation & [103] \\
\hline & miR-1281 & $\uparrow$ & HDAC4 & [104] \\
\hline & miR-155 & $\downarrow$ & - & [105] \\
\hline \multirow{5}{*}{ Treatment } & miR-122 & $\uparrow$ & CPT1A, LRP1, HINT1 & [106] \\
\hline & $\mathrm{miR}-27 \mathrm{~b}$ & $\begin{array}{l}\downarrow \text { (human T2DM } \\
\text { skeletal muscle) } \\
\uparrow \text { (diabetic mice) }\end{array}$ & NAA15 & [107-109] \\
\hline & miR-147 & $\uparrow$ & $S L C 22 A 3$ & [110] \\
\hline & miR-130a & $\downarrow$ & MAP3K12 & {$[107,111]$} \\
\hline & miR-210 & $\uparrow$ & NDUFA4 & {$[107,112]$} \\
\hline
\end{tabular}




\subsection{Beta-Cell Function}

Type 2 diabetes encompasses the combinatory effects of insulin resistance and a lack of insulin secretory response [113]. The aberrant expression of various miRNAs has been implicated in altered beta-cell function featuring T2DM pathophysiology. For instance, as an inhibitor of the insulin-AKT pathway, miR-143 presents itself as a novel biomarker for insulin tolerance and the development of T2DM [49], and miR-144 was shown to impair insulin signaling by negatively targeting insulin receptor substrate 1 (IRS1) [50]. Furthermore, miR-30d, miR-126-5p, and miR-146a-5p have all been identified as pancreas-enriched miRNAs and is implicated in diabetes pathogenesis, and the roles of miR-375, miR-21, miR-34a, miR-24.1, and miR-148 have also been investigated as potential biomarkers for T2DM [114]. In particular, the regulation of miR-375 was shown to be associated with beta-cell injury, highlighting its role in T2DM pathogenesis, and miR-15's involvement in beta-cell differentiation has also been reported [70].

As another miRNA that is directly associated with beta-cell function, miR-96 regulates pancreatic beta-cell function by inhibiting apoptosis and enhancing proliferation via targeting forkhead box protein O1 (FoxO1) and SRY-box transcription factor 6 (SOX6) [62]. The miRNA miR-199a-5p's role in hyperglycemia-induced beta-cell toxicity has also been the subject of study [63]. High glucose levels lead to an elevated expression of the miRNA, which then not only promotes reactive oxygen series (ROS) buildup but also induces apoptosis in beta cells via targeting the sirtuin 1 (SIRT1) protein. miR-124a2 is shown to target FoxA2, which is the master regulator of pancreatic development; however, the exact role it plays in pancreatic cell signaling, and hence in T2DM, remains to be fully elucidated [68]. The role of miR-9 in insulin secretion was shown to provide mediation via its targeting of Onecut-2, which is a transcription factor implicated in regulating beta-cell exocytosis [65].

Parallel to all these, some miRNAs have been shown to be protective against T2DM progression, such as miR-125b-5p, which enhanced the JNK pathway inhibition that mediated the beta-cell function in mice [64], and miR-155, which promoted insulin sensitivity, leading to insulin-mediated AKT and IRS1 phosphorylation, which in turn increased glucose uptake and glycolysis [76]. It is known to target negative regulators of insulin signaling, including histone deacetylase 4 (HDAC4), and was found to be downregulated in serum derived from T2DM patients.

\subsection{Insulin Resistance}

A considerable number of miRNAs are reported to play a role in insulin resistance, including miR-27a, miR-221, and miR-382-3p [71-73]. miR-27a, an exosomal miRNA derived from adipocytes, induces insulin resistance in skeletal tissue via inhibiting peroxisome proliferator-activator receptor gamma (PPAR $\gamma$ ) and implicates obesity-associated cell signaling. Similarly, miR-221 was shown to negatively regulate insulin sensitivity by impairing the phosphoinositide-3-kinase (PI3K)/AKT pathway in an in vivo study based on male rats, where exercise induced elevated miR-382-3p levels, which reportedly suppressed the resistin protein, negatively regulating insulin resistance in rat models. miR-128-3p also induced insulin resistance, along with cardiovascular calcification via the insulin gene enhancer protein 1 (ISL1)-dependent Wnt pathway in type 2 diabetic rats [75]. Besides these, miR-145 also plays a role in insulin resistance by targeting the PI3K/AKT pathway [54], and a low expression level of miR-223 has also been associated with insulin resistance [89].

On the other hand, miR-18a was shown to improve insulin sensitivity by targeting phosphatase and tensin homolog (PTEN), a negative regulator of the PI3K/AKT pathway, and hence, potentiating its role in treatment against T2DM [78].

\subsection{Metabolism}

miRNAs that are implicated in T2DM metabolism include miR-194's downregulation in T2DM-derived skeletal muscle [79]. This is associated with the uptake of glucose uptake, glycogen synthesis, increased glycolysis, the production of lactate, and glucose oxidation, mediated via an increased AKT and glycogen synthase kinase 3 beta (GSK3 $\beta$ ) 
phosphorylation, hence regulating glucose homeostasis. Furthermore, the role of miR-125a$5 \mathrm{p}$ in targeting signal transducer and activator of transcription 3 (STAT3), and hence regulating hepatic glycolipid metabolism in T2DM, has also been reported [84].

\subsection{Chronic Inflammation and Oxidative Stress}

Other miRNAs, such as miR-146a, were shown to be indicative of inflammation and oxidative stress, establishing their implication in T2DM pathogenesis [115], whereas miR424 negatively correlates with diabetic inflammation and oxidative stress by activating kelch-like ech associated protein 1 (KEAP1) and nuclear factor erythroid 2-related factor 2 (NRF2), leading to higher superoxide dismutase (SOD) and glutathione (GSH) levels in T2DM patients [86]. Another two anti-inflammatory miRNAs, namely, miR-181b and miR-126-5p, are reported to negatively correlate with nuclear factor kappa $B(N F-\kappa B)$ expression and hence with T2DM [87]. Similarly, miR-21 is also associated with islet inflammation and the low expression of miR-223 correlated with oxidative stress as shown in the previously discussed study by Ding et al., besides the role of miR-199a-5p in ROS generation. The decreased expression of miR-126-3p corresponded with an increased expression of vascular cell adhesion protein 1 (VCAM1), which is an endothelial inflammation marker, and decreased plasma antioxidant capacity in T2DM patients as compared to normal glucose tolerance (NGT) individuals [90].

\subsection{Clinicopathological Features of T2DM}

miRNA expression may also correlate with clinicopathological features that are associated with T2DM, including age, body mass index (BMI), gender, and ethnicity, such as the decreased expression level of miR-496 associated with the BMI-dependent upregulation of mTOR in elderly T2DM patients [91]. In a study published in 2019 on an Israeli Arab/Jewish mixed population, the expression levels of 12 candidate circulating miRNA biomarkers were determined using RT PCR expression analysis. It concluded that miR486-3p was upregulated and miR-423 downregulated in patients with T2DM with respect to healthy individuals included in the investigation as controls [92]. Furthermore, the miR-28-3p and miR-423 upregulation, and miR-486-3p downregulation was reported for complicated T2DM as compared to early T2DM cases. The signatures of 4 miRNAs (miR16-2-3p, miR-146a-5p, miR-30d, and miR-126-5p) were seen to be differentially expressed between early and complicated T2DM cases, with the addition of miR-423 only occurring for the male patients, highlighting the effect of sex differences on miRNA expression.

In another ethnic-group-specific study conducted on a Chinese Han population, miR375 was reported as a potential biomarker with aberrant methylation in its promoter region that was positively associated with T2DM [116]. A different study also investigated its methylation in two different ethnic groups, the Han and Kazak populations, reporting differential expression and hence accounting for the difference in the incidence of T2DM between these two ethnicities [117].

\subsection{Diabetic Complications}

miRNAs have also been associated with diabetic complications. For example, the expression of miR-4463 is elevated in T2DM patients with arteriosclerosis [96]. It was shown to attenuate cell apoptosis via peanut (PNUT)-mediated PTEN nuclear localization and the activation of the cell survival PI3K/AKT pathway in hypoxic and/or hyperglycemic endothelial cells. In cases of diabetic neuropathy, increased miR-196-3p and miR-203 serum levels correlated with urinary albumin excretion, which is characteristic of T2DM [97]. The role of circulating exosomal miR-20b-5p in diabetic wound healing has also been assessed [99]. This miRNA plays a role in regulating the $W n t 9 b / \beta$-cell signaling mediated suppression of human umbilical vein endothelial cell angiogenesis and cell functionality and slows wound healing. Hence, therapeutic targeting of this miRNA is shown to enhance angiogenesis and wound healing in T2DM mice models. 
The potential role of miR-423 in diabetic vascular retinal proliferation has also been studied and may be accounted for by its interaction with vascular endothelial growth factor (VEGF) signaling [100]. The differential expression of miR-10b in limbal epithelial stem cells reportedly mediates diabetic alterations [118], whereas miR-146 has been implicated in inflammation-induced diabetic neuropathy [119], while miR-1281 directly targets HDAC4 in diabetic retinopathy [104]. Moreover, miR-203-3p was found to target SMAD1, leading to the suppression of osteogenesis in diabetic patients [98] and the potential role of miR-15a in regulating initial retinal damage that is associated with early-stage T2DM has also been established [120].

In addition, single nucleotide polymorphisms (SNPs) in various miRNAs have also been studied, along with their role in diabetes and its associated complications. An miR146a SNP is shown to be associated with diabetic microvascular complications of diabetic macular oedema in Caucasian patients [121], while the polymorphism rs767649 in miR-155 was found to be associated with diabetic retinopathy [105].

\subsection{T2DM and Obesity}

miRNAs associating with obesity and T2DM include miR-15, miR-143, and let-7b [122]. Furthermore, the expression of miR-448 has also been reportedly reduced in peripheral blood in T2DM patients who had undergone laparoscopic bariatric surgery, hence highlighting its role as a prognostic marker for obese T2DM patients [123].

\subsection{Diabetic Treatment}

Ghrelin treatment of diabetic rats modulated miR-33a and miR-122's expression [124], and Liraglutinide was shown to induce increased miR-27b, miR-130a, and miR-210 serum levels in T2DM patients [103], reflecting on the possibility of a therapeutic agent's potential to modulate the miRNA regulation of genes. The expression of miR-147 was also shown to correlate with the metformin response in T2DM patients from a Pakistani population [110].

\section{4. miRNAs in Breast Cancer}

The aberrant miRNA regulation of genes that are critical for normal cell signaling is involved in various types of cancers, including breast cancer, via molecular mechanisms, such as chromosomal abnormalities, changes in transcriptional control and epigenetic regulation, and defective miRNA biogenesis machinery [125]. The study of atypically expressed miRNAs may hence be employed to develop potential diagnostic, prognostic, and therapeutic biomarkers for breast cancer. To date, there is an excessive number of miRNAs that have been discovered and are still being investigated for their potential role in breast carcinogenesis, including miR-15b, miR-10b, miR-16-2, miR-26a1, miR-17-92, miR-26a2, miR-26b, miR-126, miR-1246, miR-6861-5p, miR-1307-3p, miR-4634, miR-222, and miR-6875-5p [126-128].

Further to this, miR-362-3p was shown to have an anti-breast-cancer effect, with its expression being associated with higher survival rates in breast cancer patients [129]. At the molecular level, it negatively regulates the transcription of the human ether a-go-go related gene (HERG) potassium channels, which promote invasion and tumor proliferation; hence, its significance as a prognostic biomarker for breast cancer seems plausible. Moreover, the prognostic value of miR-383-5p has been highlighted by its role in inhibiting proliferation, migration, and invasion in breast cancer by targeting lactate dehydrogenase $A$ ( $L D H A)$ expression [130]. Its downregulated expression is concluded to be associated with differentiation and lymph node metastasis, leading to overall poor survival.

Additionally, miR-127's role in B-cell lymphoma 6 (BCL6) targeting-mediated inhibition of breast cancer growth, migration, and invasion in breast cancer cells also explains its higher expression being associated with better prognosis in breast cancer patients [131]. Controversially, miR-186 has displayed both anti- and protumorigenic properties, yet its low expression in breast cancer patients has been associated with an overall poor 
prognosis $[132,133]$. Exosomal miRNAs have also been implicated in breast cancer development [134] and miR-1282 has been shown to promote breast malignancy [135].

Moreover, numerous miRNAs have been studied for their serum levels to be employed as potential diagnostic and prognostic biomarkers for breast cancer. Khalighfard et al. found the expression levels of miR-21, miR-155, and miR-10b to be positively correlated with breast cancer, whereas let-7a showed the opposite correlation [136]. The study also showed these expression levels to respond to operative procedures, chemotherapy, and radiotherapy, all of which led to a decrease in the oncogenic miRNAs (onco-miRNAs) miR21, miR-155, and miR10b and an increase in tumor suppressor miRNA (ts-miRNA) let-7a.

Numerous animal studies have supported miRNA's role in the abnormal cellular characteristics associated with cancer, including uncontrolled growth and proliferation, apoptotic resistance, and dedifferentiation [137], with miRNAs displaying their cancerpromoting or -inhibiting properties. Hence, they have the potential to switch on their oncogenic or tumor-suppressor activity under specific conditions. This section further discusses the miRNAs that are associated with breast cancer and its hallmarks' mediating molecular mechanisms, classifying them into ts-miRNAs and onco-miRNAs, and discusses the subtype-specific expression of various miRNAs, as summarized in Table 2.

\subsection{Tumor Suppressor MiRNA}

Numerous ts-miRNAs have been identified so far. These include miR-140-5p, which has been implicated in a protective niche against breast cancer progression [143]. Although the underlying mechanism is not fully understood, a study reported that miR-140-5p targets $V E G F A$, hence inhibiting invasion and angiogenesis, and ultimately preventing breast cancer progression.

miR-590-5p, which is known to target SOX2 for negative regulation, reduced the stemness and tumorigenic properties of breast cancer cells in vitro, corresponding with its downregulation [200]. Another miRNA with antitumorigenic properties, namely, miR$449 b-5 p$, negatively impacted $W n t / \beta$-catenin signaling by inhibiting cell cycle alteration and expression-elevated protein in tumor (CREPT), which is a crucial oncogene, to induce cell cycle arrest and inhibit the invasion and growth of breast cancer cells, supported by reports of its low expression in breast cancer [138]. miR-216 also negatively regulated this particular pathway by decreasing both $W n t$ and $\beta$-catenin expression, leading to the suppression of proliferation and migration, and the induction of apoptosis by elevating caspases 3/8, Bax, and P53 in MCF7 cells [139]. miR-590-5p, which is yet another miRNA that downregulates Wnt/ $\beta$-catenin signaling, was shown to inhibit the progression of breast cancer by negatively correlating with cell migration, invasion, metastasis, and the epithelial mesenchymal transition (EMT) [140].

Further to this, miR-20a-5p also exhibited similar effects on breast cancer progression; however, it acts via targeting high mobility group A2 (HMGA2), preventing its procarcinogenic effects [141]. Huang et al. also reported on miR-219-5p as a negative regulator of migration and EMT via targeting myocardin-related transcription factor A (MRTF-A) [142].

Another miRNA that is downregulated in breast cancer is miR-322 [144]. It negatively regulates proliferation and was shown to induce apoptosis in vitro, corresponding with elevated levels of $B a x$ and the downregulation of $B C L 2$. It also reduced the invasiveness of breast cancer cells, decreasing their tendency to migrate, and was shown to correlate with NFKB1 depletion. Similarly, miR-204 was also shown to inhibit proliferation and metastasis in MCF7 breast cancer cells in vitro, which was mediated by the induction of cell cycle arrest and apoptosis [145]. It significantly inhibited $\mathrm{p}-A K T$ and $\mathrm{p}-P I 3 K$, which are two critical components of the pathway regulating cell survival. In line with this, miR-223's potential role in inhibiting proliferation and invasion in breast cancer via targeting stromal interaction molecule 1 (STIM1) was also studied [146], in parallel with its potential as a tumor biomarker by maintaining cell proliferation via the upregulation of FoxO1 [201]. 
Table 2. miRNA and target gene regulation in breast cancer.

\begin{tabular}{|c|c|c|c|c|}
\hline $\begin{array}{c}\text { Breast Cancer }(\mathrm{BC}) \\
\text { Characteristic }\end{array}$ & miRNA & Expression & Target mRNA/Implicated Pathway & Reference \\
\hline \multirow{28}{*}{ Tumor suppressor } & miR-362-3p & $\downarrow$ & HERG potassium channels & [129] \\
\hline & miR-383-5p & $\downarrow$ & LDHA & [130] \\
\hline & miR-449b-5p & $\downarrow$ & CREPT & [138] \\
\hline & $\mathrm{miR}-216$ & $\downarrow$ & Wnt/B-catenin signaling & [139] \\
\hline & miR-590-5p & $\downarrow$ & SOX2 & [140] \\
\hline & miR-20a-5p & $\downarrow$ & HMGA2 & [141] \\
\hline & miR-219-5p & $\downarrow$ & MRTFA & [142] \\
\hline & miR-140-5p & $\downarrow$ & VEGFA & [143] \\
\hline & miR-322 & $\downarrow$ & $B C L 2, N F k B 1$ & [144] \\
\hline & miR-204 & $\downarrow$ & $\mathrm{p}-A K T$ and $\mathrm{p}-P I 3 K$ & [145] \\
\hline & $\operatorname{miR}-223$ & $\downarrow$ & STIM1 & [146] \\
\hline & miR-33b & $\downarrow$ & Twist1, SALL4, HMGA2 & [147] \\
\hline & miR-31 & $\downarrow$ & RDX, RhoA, ITGA5 & [148] \\
\hline & miR-143 & $\downarrow$ & HER3 & [149] \\
\hline & miR-708-3p & $\downarrow$ & ZEB1, CDH2, Vimentin & [150] \\
\hline & miR-503 & $\downarrow$ & $I G F-1 R$ & [151] \\
\hline & miR-148a & $\downarrow$ & $B C L 2$ & [152] \\
\hline & miR-26a-5p & $\downarrow$ & RNF6, CDK4, CDK6, Cyclin D1 & [153] \\
\hline & miR-326 & $\downarrow$ & SOX12 & [154] \\
\hline & miR-671-3p & $\downarrow$ & DEPTOR & [155] \\
\hline & miR-140-3p & $\downarrow$ & RSU1 & [156] \\
\hline & let-7a(-5p) & $\downarrow$ & USP32 & {$[157,158]$} \\
\hline & miR-122 & $\downarrow$ & IGF1R & [159] \\
\hline & miR-147 & $\downarrow$ & AKT/mTOR pathway & [160] \\
\hline & miR-186 & $\downarrow$ & TWIST1 & {$[132,133]$} \\
\hline & miR-362-3p & $\downarrow$ & HERG potassium channels & [129] \\
\hline & $\mathrm{miR}-145$ & $\downarrow$ & MUC1 & [161] \\
\hline & miR-146a & $\downarrow$ & EGFR & [162] \\
\hline \multirow{11}{*}{ Oncogenic } & miR-21 & $\uparrow$ & LZTFL1 & [163] \\
\hline & $\operatorname{miR}-370$ & $\uparrow$ & WNK2 & [164] \\
\hline & miR-9 & $\uparrow$ & E-CAD, FoxO1 STARD13, LIFR & [165] \\
\hline & miR-221 & $\uparrow$ & $P T E N, E-C A D$ & [166-169] \\
\hline & miR-155 & $\uparrow$ & MAPK7 & {$[136,170]$} \\
\hline & \multirow{6}{*}{$\begin{array}{c}\text { miR-421 } \\
\text { miR-106a } \\
\text { miR-15/miR-107/miR- } \\
182 \\
\text { miR-526b/miR-655 } \\
\text { miR-409-5p } \\
\text { miR-30d }\end{array}$} & $\uparrow$ & PDCD4 & {$[171]$} \\
\hline & & $\uparrow$ & $D A X 1$ & [172] \\
\hline & & $\uparrow$ & $B R C A 1$ downregulation & [173] \\
\hline & & $\uparrow$ & TCF21, PBRM1 & [174] \\
\hline & & $\uparrow$ & RSU1 & [175] \\
\hline & & $\uparrow$ & KLF-11/STAT3 pathway & [176] \\
\hline \multirow{14}{*}{ Subtype-specific } & $\operatorname{miR}-129$ & $\downarrow(T N B C)$ & Lamin A & [177] \\
\hline & miR-218 & $\uparrow(T N B C)$ & Lamin B1 & [177] \\
\hline & miR-200c & $\downarrow(T N B C)$ & - & [178] \\
\hline & miR-200b & $\downarrow$ & Ezrin-Radixin-Moesin; SP1 & {$[179,180]$} \\
\hline & miR-191 & $\uparrow(E R+)$ & sFRP1 & {$[181,182]$} \\
\hline & $\operatorname{miR}-122 \mathrm{a}$ & $\uparrow(E R+)$ & - & [181] \\
\hline & $\operatorname{miR}-213$ & $\uparrow(E R+)$ & - & [181] \\
\hline & miR-382-5p & $\uparrow(E R+)$ & MXD1 & {$[181,183]$} \\
\hline & miR-222 & $\downarrow(E R+)$ & $E R \alpha, N O T C H 3$ & {$[181,184,185]$} \\
\hline & $\operatorname{miR}-497$ & $\uparrow(T N B C, H E R 2+)$ & SMAD7 & [186] \\
\hline & let-7a-5p & $\downarrow(T N B C)$ & GLUT12 & [187] \\
\hline & miR-18a & $\uparrow$ & $H I F 1 \alpha$ & [188-190] \\
\hline & miR-126-3p & $\downarrow(T N B C)$ & RGS3 & [191] \\
\hline & miR-124a & $\downarrow(I D C)$ & - & [192] \\
\hline \multirow{2}{*}{ Clinicopathology } & miR-520g & $\uparrow$ & $p 53$ & [193] \\
\hline & miR-4732-5p & $\downarrow$ & TSPAN13 & [194] \\
\hline \multirow{4}{*}{ Treatment } & $\mathrm{miR}-663 \mathrm{~b}$ & $\uparrow$ & TP73 & [195] \\
\hline & miR-7 & $\uparrow$ & SETDB1, RELA/STAT3 pathway & [196-198] \\
\hline & miR-1282 & $\downarrow$ & - & [135] \\
\hline & $\operatorname{miR}-27 a$ & $\uparrow$ & $A M P K 2 \alpha$ & [199] \\
\hline
\end{tabular}

Moreover, other miRNAs that were shown to serve as negative regulators of breast cancer metastasis include miR-33b [147], miR-31 and miR-143 [202], miR-708-3p [150], and miR-204. miR-33b was shown to negatively correlate with lymph node metastasis and its 
target genes, including Twist1, spalt-like transcription factor 4 (SALL4), and HMGA2, through which, it inhibits self-renewal, migration, and invasion [66]. miR-31 was shown to be more potent in suppressing breast cancer metastasis and invasion as compared to miR-143, and miR-708-3p exhibited its tumor-suppressing activity by inhibiting EMT via targeting the EMT mediators zinc finger E-box binding homeobox 1 (ZEB1), cadherin 2 (CDH2), and vimentin, suppressing breast cancer metastasis and countering chemoresistance. Previously, miR-204 and miR-147 were also shown to mediate their tumor-suppressing effect on proliferation, invasion, and metastasis via targeting of the PI3K/AKT pathway $[145,160]$.

Yet another miRNA of particular interest is miR-503, which is known to inhibit insulinlike growth factor 1 receptor (IGF-1R), altering insulin signaling, and hence, counteracting IGF1R's role in breast cancer progression [151]. miR-148a targets BCL2, which is an antiapoptotic factor, reducing its expression, and hence, leading to decreased proliferation and increased apoptosis, as reported in breast cancer cells [152]. Another study showed that miR-26a-5p downregulated ring finger protein 6 (RNF6), cyclin-dependent kinase 4 (CDK4), $C D K 6$, and cyclin D1 expression, upregulated $p 21, p 27$, and $p 53$ expression, and modulated estrogen receptor alpha $(E R \alpha)$ protein stability, leading to the inhibition of breast cancer growth [153]. This correlates with its low expression in breast cancer and association with overall poor survival in breast cancer patients. Furthermore, miR-326, with its tumorsuppressing activity, suppresses the proliferation, migration, and invasion of cancer, by targeting and regulating SOX12, and it was shown to be downregulated in breast cancer patients [154].

miR-671-3p, as shown in an in vitro study, is also downregulated in breast cancer cells, correlating with its DEP domain containing mTOR interacting protein (DEPTOR)-inhibitionmediated suppression of proliferation and invasion in MDA-MB-231, MCF-7, and SKBR3 cells [155]. Another miRNA, miR-140-3p, which is underexpressed in breast cancer, inhibited cell cycle progression and proliferation in vitro, outlining its tumor-suppressing potential [156]. miR-146a also inhibited proliferation, invasion, and metastasis by directly targeting the $3^{\prime}$ UTR region of epidermal growth factor receptor (EGFR) mRNA [162] and miR145 by targeting the metastasis regulator gene mucin 1 (MUC1) [161,203]. Additionally, let7a-5p and miR-21-5p were identified as potential noninvasive biomarkers for the diagnosis of breast cancer metastasis with reduced expression in breast cancer [157], while miR-361$3 p$ 's low expression was also implicated in promoting breast cancer [204].

\subsection{Oncogenic miRNAs}

miRNAs that were shown to promote proliferation in breast cancer include miR-21 and miR-370 [163,164]. In vivo studies showed the miR-21 mechanism of action to associate with its target gene LZTFL1, which is a leucine zipper transcription factor. miR-370 also promotes cell proliferation and correlates with poor breast cancer prognosis; however, the underlying mechanism is still unclear, although its oncogenic activity has been associated with downregulating its downstream target WNK2.

Furthermore, miR-9 was implicated in breast cancer initiation and progression and was shown to promote metastasis in breast cancer [165]. Its expression and that of miR-221 in human breast cancer have been associated with poor differentiation, larger tumor size, lymph node metastasis, and an advanced stage [205].

Other miRNAs that are upregulated in breast cancer and positively associate with its progression include miR-155 via its potential targeting of mitogen-activated protein kinase 7 (MAPK7), as shown by bioinformatics analysis and validation via a positively correlated expression pattern [170], and miR-421, which was found to be upregulated in MCF-7 and MDA-MB-231 breast cancer cell lines, as it promoted proliferation, migration, and invasion and inhibited apoptosis via its target gene known as programmed cell death 4 (PDCD 4) [171]. Moreover, miR-106a was shown to promote breast cancer by negatively regulating dosage-sensitive sex reversal in the adrenal hypoplasia critical region on chromosome X gene 1 (DAX1) [172]. 
In addition, miR-15, miR-107, and miR-182 mediate the reduced expression of breast cancer type 1 susceptibility protein (BRCA1), leading to dysregulated DNA repair [173], while $\mathrm{miR}-526 \mathrm{~b}$ and miR-655 expression corresponded to oxidative stress and the expression of thioredoxin reductase 1 (TXNRD1) in a previously published study, both of which were positively associated with breast cancer. While increased oxidative stress causes defects in DNA repair machinery, TXNRD1 levels are regulated by transcription factor 21 (TCF21) and polybromo 1 (PBRM1), which are two downstream targets of miR526b/miR-655 [174]. Furthermore, miR-30d exhibits its oncogenic potential by promoting breast cancer cell migration, invasion, and EMT by modulating the kruppel-like factor 11 (KLF11)-STAT3 axis [176]. miR-409-5p is also upregulated in breast cancer and its inhibition is shown to mediate anticancerous effects via the subsequent upregulation of its downstream target, namely, Ras suppressor protein 1 (RSU1) [175].

\subsection{Clinicopathology of Breast Cancer and Its Subtypes}

Different subtypes of breast cancer vary in their molecular expression profiles, including miRNAs such as the miR-124a, which is one of the most frequently methylated miRNA genes in cancer and is interlinked with tumor growth and aggressiveness in invasive ductal carcinoma [192]. Hence, miRNAs that are distinctly expressed in specific subtypes may be employed to diagnose a disease subtype and allow for better disease management and treatment. This has been validated by multiple studies, including the 46-miRNA signature that was already identified, which could differentiate between breast cancer subtypes [206].

Setijono et al. studied the downregulation of tumor-suppressing miR-129 and upregulation of oncogenic miR-218 in triple-negative breast cancer (TNBC), associating these two miRNAs to the deregulation of lamin A and lamin B1, respectively, which are common to human breast cancers [177]. Moreover, the reduced expression of miR-126-3p in TNBC cell lines corresponded with regulator of G-protein signaling 3 (RGS3)-inhibition-mediated suppression of cell proliferation, angiogenesis, migration, and invasion [191].

Another study on the aberrant expression of miRNAs in ER-positive breast cancer showed an increased expression of miR-191, miR-122a, miR-213, and miR-382-5p, and decreased expression levels of miR-125b-1, miR-125b-2, and miR-145 [181].

In a cross-subtype comparison, miR-200c was shown to be differentially expressed between TNBC and ER+/PR+ groups, with its expression being significantly lower in (TNBC) [178]. miR-200b was also found to be differentially expressed between two breast cancer cell lines, namely, MDA-MB-231 and MCF-7, with the expression being significantly higher in the latter and its expression negatively correlating with Ezrin-Radixin-Moesin mediated cell migration and invasion [179]. In another instance, miR-497 post-transcriptionally regulates $S M A D 7$, and hence promotes proliferation, particularly in overexpressed HER2+ breast cancer and TNBC [186]. Contrary to this, miR-18a reportedly prevented distant metastases by directly targeting hypoxia-inducible factor 1 alpha subunit (HIF1 $\alpha$ ) [188]; however, it has also been associated with poor overall survival, particularly in luminal breast cancers, and is overexpressed in TNBC $[189,190]$.

Moreover, miRNA expression may also correlate with disease stage, grade, and other clinicopathological features. For instance, plasma miR-520g was found to be overexpressed in breast cancer patients, associating positively with lymph node metastasis, low differentiation grade, and invasion, and negatively with $p 53$ expression, signifying its prognostic value [193]. The expression of miR-106a, with its oncogenic potential, as already discussed, was also shown to positively correlate with higher tumor stage, lymph node and distant metastases, and overall poorer prognosis.

The dual, yet contradictory, role of miR-4732-5p has also been studied. Its significant downregulation in breast cancer samples reflects on its tumor-suppressing role in breast cancer initiation; however, it associates positively with clinicopathological features, such as high Ki-67 levels, grade, larger tumor size, lymph node metastasis, late clinical stage, and poor prognosis, indicating its oncogenic potential. It was shown to mediate these effects via its targeting and suppression of tetraspanin 13 (TSPAN13) expression [194]. 


\subsection{Breast Cancer Treatments}

miRNA regulation has also been implicated in crosstalk with breast cancer therapeutic agents. miR-663b was shown to play a role in tamoxifen resistance in breast cancer by implicating the downregulation of its direct target gene tumor protein 73 (TP73) in MCF-7 cells [195], while miR-7 not only associates with poor primary breast cancer prognosis but also correlates negatively with the tamoxifen response and overall poor post-relapse and progression-free survival [196].

\section{5. miRNA's Regulatory Reigns on the T2DM-Breast Cancer Association}

With a non-exhaustive list of miRNAs implicated in these two complex, metabolic diseases, particularly in breast cancer, several miRNAs have been identified as mediating aberrant gene regulation, contributing to both diseases' progression. Previously, miR-448 was shown to play a role in determining the adhesive and angiogenic potential of endothelial progenitor cells (EPCs) and is known to suppress viability and invasion. Moreover, circulating miRNAs with an endocrine function include miR-122-5p, which is dominantly expressed in the liver and shows tumor suppressor properties [159,207], whereas the loss of miR-145 expression was shown to contribute toward breast cancer development and progression in patients with both breast cancer and T2DM [208]. Additionally, miR-148 and $\mathrm{miR}-125 \mathrm{~b}$ have also been implicated with both diseases.

In continuation with this, the miRNAs discussed earlier in this review, i.e., 53 for T2DM and 62 for breast cancer, were utilized to identify a 20-miRNA signature that is common to both T2DM and breast cancer by employing a Venn diagram analysis performed on Funrich software [209], as shown in Figure 2.

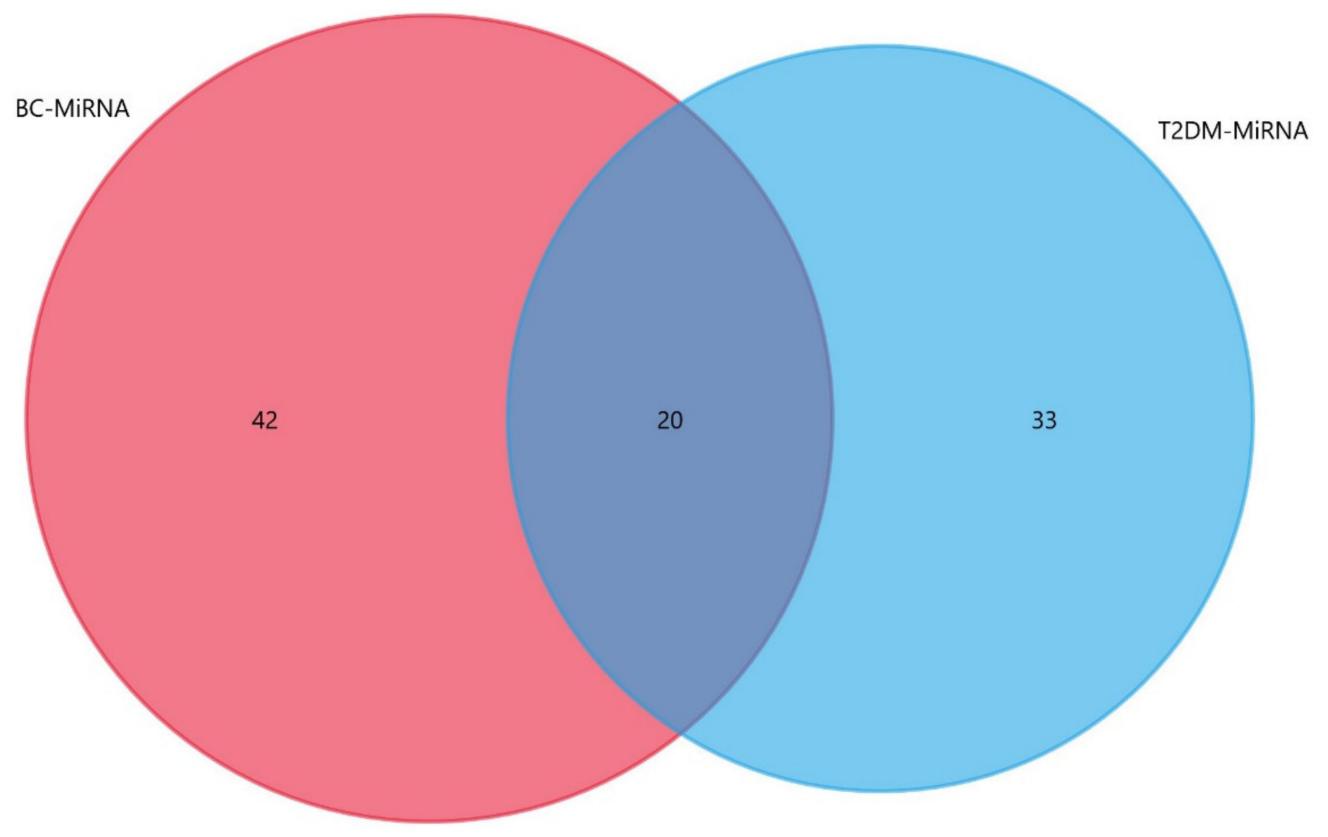

Figure 2. Signature miRNA overlap between T2DM and BC regulatory miRNA Networks. Each circle represents a disease-specific miRNA subset, with the intersection representing a signature of 20 miRNAs that are common to both T2DM and breast cancer.

These miRNAs that are common to both T2DM and breast cancer are miR-18a, miR223, miR-33b, miR-143, miR-145, miR-147, miR-186, miR-27a, miR-21, miR-9, miR-221, miR-222, miR-155, miR-15, miR-182, miR-30d, miR-126-3p, miR-146a, miR-122, and miR124a. This miRNA overlap between the miRNA regulatory networks of T2DM and breast cancer signifies the potential implication of each of these miRNAs in T2DM-breast cancer (BC) crosstalk, hence providing a window to further probe into the miRNA-mediated 
molecular basis of the T2DM-BC association. Therefore, understanding their role in T2DM, breast cancer, and the comorbid state is crucial.

So far, the roles of miRNA-124a and miR-30d have already been established in patients with both breast cancer and diabetes, with their expression levels positively correlating with diabetic characteristics, including the insulin resistance index, BMI, and glycosylated hemoglobin [210]. Another study has implicated it in pancreatic development and insulin secretion [211]. Their expression levels are also shown to correlate with clinicalpathological features of breast cancer in patients with both comorbidities [212], and the development of breast cancer with T2DM; however, the underlying mechanism is still not clear. Another study correlated these miRNAs' expression with the downregulation of caveolin-1 (CAV1)-mediated activation of estrogen receptor signaling and its crosstalk with insulin signaling to increase the serum insulin level [213].

Similarly, another two miRNAs that activate the estrogen receptor by downregulating CAV1 are miR-221 and miR-222, and the overexpression of these two miRNAs is associated with poor breast cancer prognosis and is positively correlated with the insulin resistance index [214]. Besides their implication in T2DM and breast cancer individually, these are also aberrantly expressed in patients with both diabetes and postmenopausal breast cancer [215]. At the molecular level, the decreased expression of CAV1 also leads to decreased insulin sensitivity, and hence, the development of insulin resistance and estrogen signaling contributes to breast cancer.

Furthermore, Liraglutinide's inhibitory effect on the miR-27a level, and subsequently elevated levels of AMP-activated kinase 2 alpha (AMPK2 $\alpha$ ) in MCF-7 cells, was also reported [199], and miR-122, besides its role in T2DM etiology, has also been implicated in breast cancer. It was found to target IGF1R, inhibiting cell proliferation and tumorigenesis [159].

Hence, out of the 20 miRNAs identified, previously published literature has already discussed 6 of these miRNAs in the context of the T2DM-BC dual relationship. As for the remaining 14 miRNAs, relating the expression patterns of each of these for either disease may provide clues into their potential role in mediating the phenotypic changes underlying the T2DM-BC crosstalk, as illustrated in Figure 3.

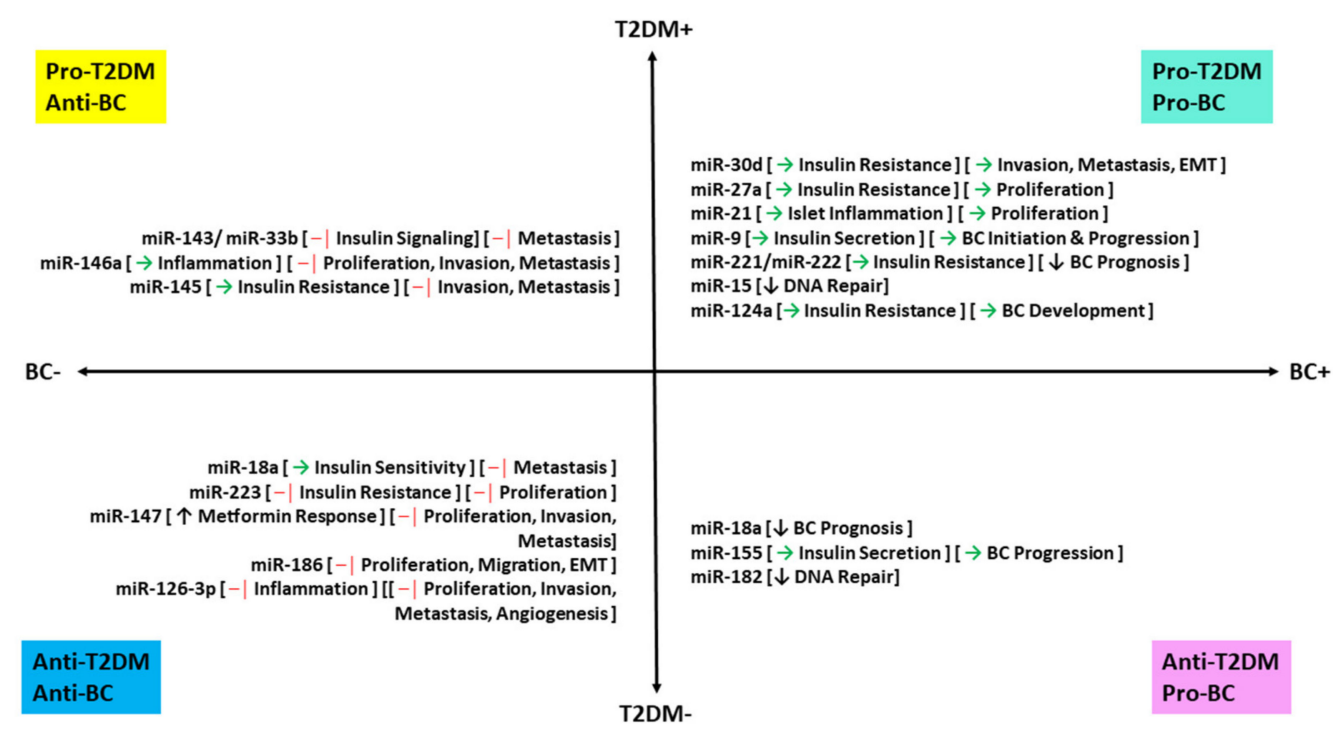

Figure 3. Regulatory miRNA overlap in T2DM and breast cancer. Symbols: $\rightarrow$ represents activation, $-\mid$ represents inhibition, $\uparrow$ represents upregulation, and $\downarrow$ represents downregulation.

For instance, miR-122, miR-143, miR-223, miR-33b, miR-145, miR-147, miR-18a, miR124a, and miR-155 are differentially expressed; miR-21, miR-9, miR-27a, miR-15, and miR-182 are upregulated miRNAs; miR-186, miR-126-3p, and miR-146a are downregulated 
miRNAs in both diseases. Their expression, coupled with the subsequent implication on their target genes, may provide insight into the potential roles of these miRNAs as diagnostic, prognostic (particularly quadrant I in Figure 3), or therapeutic biomarkers (especially those falling into quadrant III in Figure 3) for comorbid patients. However, the roles of each of these miRNAs need to be studied in patients with both comorbidities to fully understand their potential niche in diabetes-breast cancer crosstalk.

In summary, there are numerous miRNAs, some of which were previously established, along with the additional miRNAs identified here, which may be implicated in mediating T2DM-induced breast carcinogenesis and T2DM onset in diabetic patients. To validate this overlap in the T2DM and BC miRNA regulatory networks, it is necessary to conduct further research on the potential role of miRNAs associated with T2DM, in breast carcinogenesis, and of those associated with breast cancer in the onset of T2DM in breast cancer patients, along with the identification of other novel miRNAs to fully comprehend the extent of the miRNA-mediated gene regulatory network underlying the molecular bridge between diabetes and breast cancer.

\section{Future of miRNAs in T2DM and Breast Cancer}

With several complexities underlying T2DM and breast cancer, the miRNAs highlighted in this review may just be a small sample of those involved. Many other miRNAs are associated with T2DM and breast cancer; however, their association and the underlying mechanisms are not fully clear. These include miR-155, which was shown to be downregulated in T2DM patients [105]; miR-330, which positively associates with T2DM pathogenesis [216]; miR-802-5p [217], miR-126, and miR-146a with T2DM [218]. Similarly, molecular mechanisms underlying numerous other miRNAs implicated in breast cancer are not fully understood and further investigation is required to establish their roles as potential diagnostic or prognostic markers, and even potential therapeutic targets for breast cancer.

\section{Conclusions}

With increasing molecular evidence establishing the T2DM-BC association, a considerable number of miRNAs have been implicated in mediating this interdisease transitionary crosstalk, highlighting a significant overlap in the miRNA regulatory networks underlying diabetes and breast cancer. This study identified a 20-miRNA signature that is common to both T2DM and breast cancer, of which, 6 were previously implicated in the T2DM-BC association. However, to fully acknowledge the depth of this relationship, there is a pressing need for further in-depth molecular studies to elucidate the roles of each of these miRNAs identified in the T2DM-BC association. These may then be employed to provide novel therapeutic targets and thereafter counter the elevated risk of breast cancer in diabetic patients and enhance the prognosis in breast cancer patients with the onset of diabetes.

Author Contributions: All authors contributed to the conceptualization, writing (original draft preparation, review, editing), and visualization for this paper. All authors have read and agreed to the published version of the manuscript.

Funding: This research received no external funding.

Conflicts of Interest: The authors declare no conflict of interest.

$\begin{array}{ll}\text { Abbreviations } \\ \text { RNA } & \text { Ribonucleic acid } \\ \text { DNA } & \text { Deoxyribonucleic acid } \\ \text { DCGR8 } & \text { DiGeorge critical region } \\ \text { ORP8 } & \text { Oxysterol binding related protein } 8 \\ \text { IRS } & \text { Insulin receptor substrate } \\ \text { RUNX2 } & \text { Runt-related transcription factor 2 } \\ \text { ERK } & \text { Extracellular-signal-regulated kinase }\end{array}$




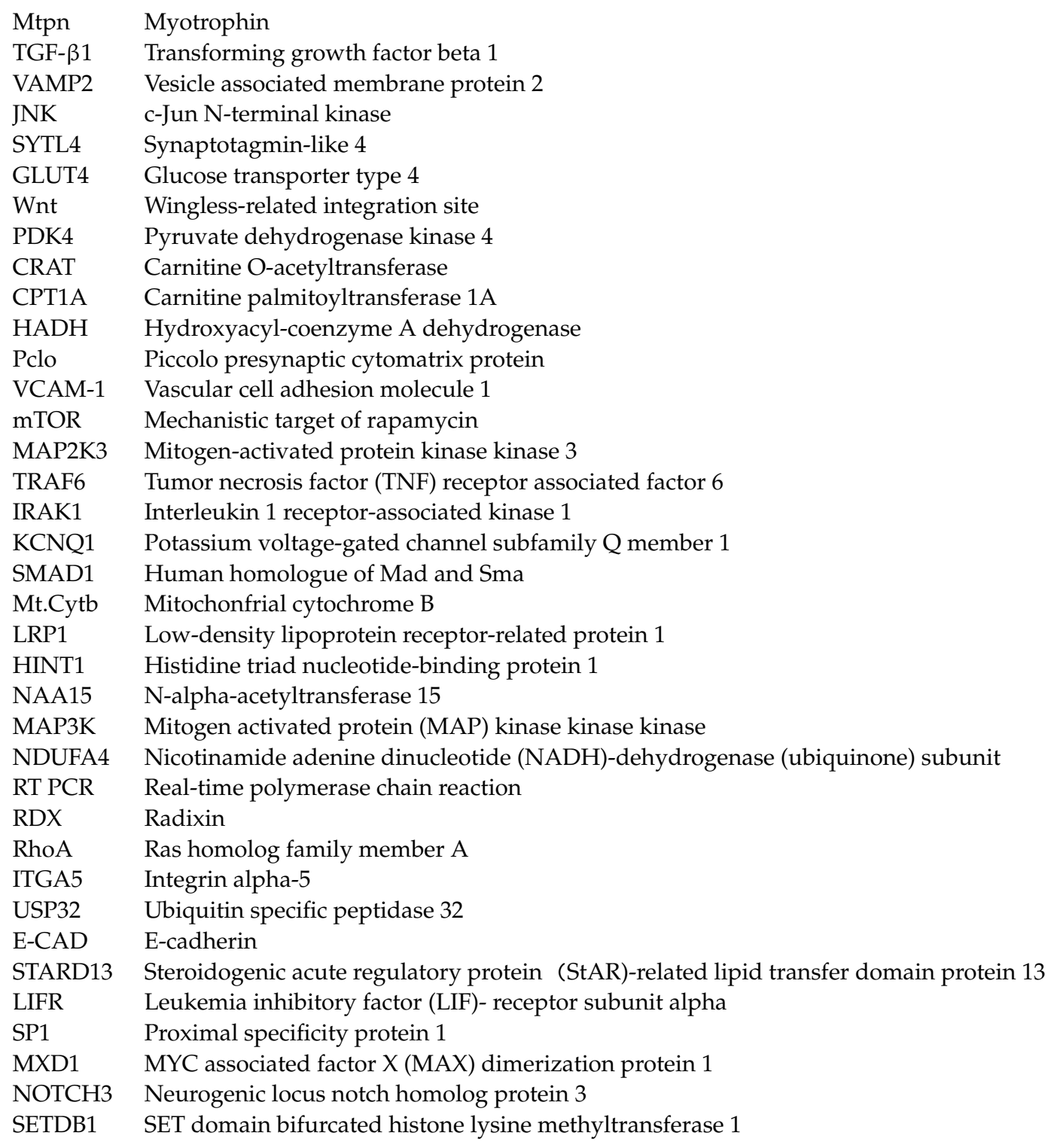

\section{References}

1. Crick, F. Central Dogma of Molecular Biology. Nature 1970, 227, 561-563. [CrossRef]

2. Makarova, J.A.; Shkurnikov, M.U.; Wicklein, D.; Lange, T.; Samatov, T.R.; Turchinovich, A.A.; Tonevitsky, A.G. Intracellular and Extracellular MicroRNA: An Update on Localization and Biological Role. Prog. Histochem. Cytochem. 2016, 51, 33-49. [CrossRef]

3. Naqvi, A.R.; Islam, M.N.; Choudhury, N.R.; Haq, Q.; Mohd, R. The Fascinating World of RNA Interference. Int. J. Biol. Sci. 2009, 97-117. [CrossRef] [PubMed]

4. Rolle, K.; Piwecka, M.; Belter, A.; Wawrzyniak, D.; Jeleniewicz, J.; Barciszewska, M.Z.; Barciszewski, J. The Sequence and Structure Determine the Function of Mature Human MiRNAs. PLoS ONE 2016, 11, e0151246. [CrossRef]

5. $\quad$ Lee, Y.; Kim, M.; Han, J.; Yeom, K.-H.; Lee, S.; Baek, S.H.; Kim, V.N. MicroRNA Genes Are Transcribed by RNA Polymerase II. EMBO J. 2004, 23, 4051-4060. [CrossRef]

6. Schanen, B.C.; Li, X. Transcriptional Regulation of Mammalian MiRNA Genes. Genomics 2011, 97, 1-6. [CrossRef]

7. Ha, M.; Kim, V.N. Regulation of MicroRNA Biogenesis. Nat. Rev. Mol. Cell Biol. 2014, 15, 509-524. [CrossRef] [PubMed]

8. Yoda, M.; Kawamata, T.; Paroo, Z.; Ye, X.; Iwasaki, S.; Liu, Q.; Tomari, Y. ATP-Dependent Human RISC Assembly Pathways. Nat. Struct. Mol. Biol. 2010, 17, 17-23. [CrossRef] [PubMed]

9. Hammond, S.M. An Overview of MicroRNAs. Adv. Drug Deliv. Rev. 2015, 87, 3. [CrossRef]

10. Khvorova, A.; Reynolds, A.; Jayasena, S.D. Functional SiRNAs and MiRNAs Exhibit Strand Bias. Cell 2003, 115, $209-216$. [CrossRef]

11. Schwarz, D.S.; Hutvágner, G.; Du, T.; Xu, Z.; Aronin, N.; Zamore, P.D. Asymmetry in the Assembly of the RNAi Enzyme Complex. Cell 2003, 115, 199-208. [CrossRef]

12. Doench, J.G.; Sharp, P.A. Specificity of MicroRNA Target Selection in Translational Repression. Genes Dev. 2004, 18, 504-511. [CrossRef] 
13. Vella, M.C.; Choi, E.-Y.; Lin, S.-Y.; Reinert, K.; Slack, F.J. The C. Elegans MicroRNA Let-7 Binds to Imperfect Let-7 Complementary Sites from the Lin-41 3'UTR. Genes Dev. 2004, 18, 132-137. [CrossRef] [PubMed]

14. Brennecke, J.; Stark, A.; Russell, R.B.; Cohen, S.M. Principles of MicroRNA-Target Recognition. PLoS Biol. 2005, 3, e85. [CrossRef] [PubMed]

15. Felekkis, K.; Touvana, E.; Stefanou, C.; Deltas, C. MicroRNAs: A Newly Described Class of Encoded Molecules That Play a Role in Health and Disease. Hippokratia 2010, 14, 236-240. [PubMed]

16. Loh, H.-Y.; Norman, B.P.; Lai, K.-S.; Rahman, N.M.A.N.A.; Alitheen, N.B.M.; Osman, M.A. The Regulatory Role of MicroRNAs in Breast Cancer. Int. J. Mol. Sci. 2019, 20, 4940. [CrossRef]

17. Zhou, S.-S.; Jin, J.-P.; Wang, J.-Q.; Zhang, Z.-G.; Freedman, J.H.; Zheng, Y.; Cai, L. MiRNAS in Cardiovascular Diseases: Potential Biomarkers, Therapeutic Targets and Challenges. Acta Pharm. Sin. 2018, 39, 1073-1084. [CrossRef]

18. Long, H.; Wang, X.; Chen, Y.; Wang, L.; Zhao, M.; Lu, Q. Dysregulation of MicroRNAs in Autoimmune Diseases: Pathogenesis, Biomarkers and Potential Therapeutic Targets. Cancer Lett. 2018, 428, 90-103. [CrossRef]

19. Tan, W.; Liu, B.; Qu, S.; Liang, G.; Luo, W.; Gong, C. MicroRNAs and Cancer: Key Paradigms in Molecular Therapy. Oncol. Lett. 2018, 15, 2735-2742. [CrossRef] [PubMed]

20. Mandujano-Tinoco, E.A.; García-Venzor, A.; Melendez-Zajgla, J.; Maldonado, V. New Emerging Roles of MicroRNAs in Breast Cancer. Breast Cancer Res. Treat. 2018, 171, 247-259. [CrossRef]

21. Vaishya, S.; Sarwade, R.D.; Seshadri, V. MicroRNA, Proteins, and Metabolites as Novel Biomarkers for Prediabetes, Diabetes, and Related Complications. Front. Endocrinol. 2018, 9. [CrossRef]

22. Ullah, S.; John, P.; Bhatti, A. MicroRNAs with a Role in Gene Regulation and in Human Diseases. Mol. Biol. Rep. 2014, 41, 225-232. [CrossRef]

23. Kaur, P.; Kotru, S.; Singh, S.; Behera, B.S.; Munshi, A. Role of MiRNAs in the Pathogenesis of T2DM, Insulin Secretion, Insulin Resistance, and $\beta$ Cell Dysfunction: The Story so Far. J. Physiol. Biochem. 2020, 76, 485-502. [CrossRef]

24. Tudzarova, S.; Osman, M.A. The Double Trouble of Metabolic Diseases: The Diabetes-Cancer Link. Mol. Biol. Cell 2015, 26, 3129-3139. [CrossRef]

25. Giovannucci, E.; Harlan, D.M.; Archer, M.C.; Bergenstal, R.M.; Gapstur, S.M.; Habel, L.A.; Pollak, M.; Regensteiner, J.G.; Yee, D. Diabetes and Cancer: A Consensus Report. Diabetes Care 2010, 33, 1674-1685. [CrossRef] [PubMed]

26. Lee, K.N.; Torres, M.A.; Troeschel, A.N.; He, J.; Gogineni, K.; McCullough, L.E. Type 2 Diabetes, Breast Cancer Specific and Overall Mortality: Associations by Metformin Use and Modification by Race, Body Mass, and Estrogen Receptor Status. PLoS ONE 2020, 15. [CrossRef] [PubMed]

27. Mantovani, A.; Targher, G. Type 2 Diabetes Mellitus and Risk of Hepatocellular Carcinoma: Spotlight on Nonalcoholic Fatty Liver Disease. Ann. Transl. Med. 2017, 5. [CrossRef] [PubMed]

28. Li, D. Diabetes and Pancreatic Cancer. Mol. Carcinog. 2012, 51, 64-74. [CrossRef] [PubMed]

29. Saed, L.; Varse, F.; Baradaran, H.R.; Moradi, Y.; Khateri, S.; Friberg, E.; Khazaei, Z.; Gharahjeh, S.; Tehrani, S.; Sioofy-Khojine, A.-B.; et al. The Effect of Diabetes on the Risk of Endometrial Cancer: An Updated a Systematic Review and Meta-Analysis. BMC Cancer 2019, 19, 527. [CrossRef]

30. Hardefeldt, P.J.; Edirimanne, S.; Eslick, G.D. Diabetes Increases the Risk of Breast Cancer: A Meta-Analysis. Endocr. Relat. Cancer 2012, 19, 793-803. [CrossRef]

31. Ma, Y.; Yang, W.; Song, M.; Smith-Warner, S.A.; Yang, J.; Li, Y.; Ma, W.; Hu, Y.; Ogino, S.; Hu, F.B.; et al. Type 2 Diabetes and Risk of Colorectal Cancer in Two Large U.S. Prospective Cohorts. Br. J. Cancer 2018, 119, 1436-1442. [CrossRef]

32. Xu, Y.; Huo, R.; Chen, X.; Yu, X. Diabetes Mellitus and the Risk of Bladder Cancer. Medicine 2017, 96. [CrossRef] [PubMed]

33. Feng, X.; Song, M.; Preston, M.A.; Ma, W.; Hu, Y.; Pernar, C.H.; Stopsack, K.H.; Ebot, E.M.; Fu, B.C.; Zhang, Y.; et al. The Association of Diabetes with Risk of Prostate Cancer Defined by Clinical and Molecular Features. Br. J. Cancer 2020, 123, 657-665. [CrossRef]

34. Hall, G.C.; Roberts, C.M.; Boulis, M.; Mo, J.; MacRae, K.D. Diabetes and the Risk of Lung Cancer. Diabetes Care 2005, 28 , 590-594. [CrossRef]

35. Abudawood, M. Diabetes and Cancer: A Comprehensive Review. J. Res. Med. Sci. 2019, 24. [CrossRef]

36. Ferguson, R.D.; Gallagher, E.J.; Scheinman, E.J.; Damouni, R.; LeRoith, D. The Epidemiology and Molecular Mechanisms Linking Obesity, Diabetes, and Cancer. Vitam. Horm. 2013, 93, 51-98. [CrossRef] [PubMed]

37. Gutiérrez-Salmerón, M.; Chocarro-Calvo, A.; García-Martínez, J.M.; de la Vieja, A.; García-Jiménez, C. Epidemiological Bases and Molecular Mechanisms Linking Obesity, Diabetes, and Cancer. Endocrinol. Diabetes Nutr. 2017, 64, 109-117. [CrossRef] [PubMed]

38. Yaribeygi, H.; Sathyapalan, T.; Atkin, S.L.; Sahebkar, A. Molecular Mechanisms Linking Oxidative Stress and Diabetes Mellitus. Available online: https:/ / www.hindawi.com/journals/omcl/2020/8609213/ (accessed on 27 January 2021).

39. LaPierre, M.P.; Stoffel, M. MicroRNAs as Stress Regulators in Pancreatic Beta Cells and Diabetes. Mol. Metab. 2017, 6, 1010-1023. [CrossRef]

40. Calderari, S.; Diawara, M.R.; Garaud, A.; Gauguier, D. Biological Roles of MicroRNAs in the Control of Insulin Secretion and Action. Physiol. Genom. 2016, 49, 1-10. [CrossRef]

41. Yan, L.-N.; Zhang, X.; Xu, F.; Fan, Y.-Y.; Ge, B.; Guo, H.; Li, Z.-L. Four-MicroRNA Signature for Detection of Type 2 Diabetes. World J. Clin. Cases 2020, 8, 1923-1931. [CrossRef] 
42. Rezk, N.A.; Sabbah, N.A.; Saad, M.S.S. Role of MicroRNA 126 in Screening, Diagnosis, and Prognosis of Diabetic Patients in Egypt. IUBMB Life 2016, 68, 452-458. [CrossRef]

43. Weale, C.J.; Matshazi, D.M.; Davids, S.F.G.; Raghubeer, S.; Erasmus, R.T.; Kengne, A.P.; Davison, G.M.; Matsha, T.E. Circulating MiR-30a-5p and MiR-182-5p in Prediabetes and Screen-Detected Diabetes Mellitus. Diabetes Metab. Syndr. Obes. 2020, 13, 5037-5047. [CrossRef] [PubMed]

44. Sun, K.; Chang, X.; Yin, L.; Li, J.; Zhou, T.; Zhang, C.; Chen, X. Expression and DNA Methylation Status of MicroRNA-375 in Patients with Type 2 Diabetes Mellitus. Mol. Med. Rep. 2014, 9, 967-972. [CrossRef] [PubMed]

45. Taheri, M.; Eghtedarian, R.; Ghafouri-Fard, S.; Omrani, M.D. Non-Coding RNAs and Type 2 Diabetes Mellitus. Arch. Physiol. Biochem. 2020, 1-10. [CrossRef]

46. Kim, M.; Zhang, X. The Profiling and Role of MiRNAs in Diabetes Mellitus. J. Diabetes Clin. Res. 2019, 1, 5-23. [CrossRef] [PubMed]

47. Vasu, S.; Kumano, K.; Darden, C.M.; Rahman, I.; Lawrence, M.C.; Naziruddin, B. MicroRNA Signatures as Future Biomarkers for Diagnosis of Diabetes States. Cells 2019, 8, 1533. [CrossRef]

48. Yang, Z.; Chen, H.; Si, H.; Li, X.; Ding, X.; Sheng, Q.; Chen, P.; Zhang, H. Serum MiR-23a, a Potential Biomarker for Diagnosis of Pre-Diabetes and Type 2 Diabetes. Acta Diabetol. 2014, 51, 823-831. [CrossRef] [PubMed]

49. Li, B.; Fan, J.; Chen, N. A Novel Regulator of Type II Diabetes: MicroRNA-143. Trends Endocrinol. Metab. 2018, 29, 380-388. [CrossRef]

50. Karolina, D.S.; Armugam, A.; Tavintharan, S.; Wong, M.T.K.; Lim, S.C.; Sum, C.F.; Jeyaseelan, K. MicroRNA 144 Impairs Insulin Signaling by Inhibiting the Expression of Insulin Receptor Substrate 1 in Type 2 Diabetes Mellitus. PLoS ONE 2011, 6, e22839. [CrossRef]

51. Tang, X.; Muniappan, L.; Tang, G.; Ozcan, S. Identification of Glucose-Regulated MiRNAs from Pancreatic \{beta\} Cells Reveals a Role for MiR-30d in Insulin Transcription. RNA 2009, 15, 287-293. [CrossRef] [PubMed]

52. Lu, Y.; Ryan, S.L.; Elliott, D.J.; Bignell, G.R.; Futreal, P.A.; Ellison, D.W.; Bailey, S.; Clifford, S.C. Amplification and Overexpression of Hsa-MiR-30b, Hsa-MiR-30d and KHDRBS3 at 8q24.22-Q24.23 in Medulloblastoma. PLoS ONE 2009, 4, e6159. [CrossRef]

53. Zaragosi, L.-E.; Wdziekonski, B.; Brigand, K.L.; Villageois, P.; Mari, B.; Waldmann, R.; Dani, C.; Barbry, P. Small RNA Sequencing Reveals MiR-642a-3p as a Novel Adipocyte-Specific MicroRNA and MiR-30 as a Key Regulator of Human Adipogenesis. Genome Biol. 2011, 12, R64. [CrossRef]

54. Huang, Y.; Yan, Y.; Xv, W.; Qian, G.; Li, C.; Zou, H.; Li, Y. A New Insight into the Roles of MiRNAs in Metabolic Syndrome. Available online: https:/ / www.hindawi.com/journals/bmri/2018/7372636/ (accessed on 28 January 2021).

55. Ryu, H.S.; Park, S.-Y.; Ma, D.; Zhang, J.; Lee, W. The Induction of MicroRNA Targeting IRS-1 Is Involved in the Development of Insulin Resistance under Conditions of Mitochondrial Dysfunction in Hepatocytes. PLoS ONE 2011, 6, e17343. [CrossRef]

56. Mann, M.; Mehta, A.; Zhao, J.L.; Lee, K.; Marinov, G.K.; Garcia-Flores, Y.; Lu, L.-F.; Rudensky, A.Y.; Baltimore, D. An NF-KBMicroRNA Regulatory Network Tunes Macrophage Inflammatory Responses. Nat Commun. 2017, 8, 851. [CrossRef]

57. Ling, H.-Y.; Wen, G.-B.; Feng, S.-D.; Tuo, Q.-H.; Ou, H.-S.; Yao, C.H.; Zhu, B.-Y.; Gao, Z.-P.; Zhang, L.; Liao, D.-F. MicroRNA-375 Promotes 3T3-L1 Adipocyte Differentiation through Modulation of Extracellular Signal-Regulated Kinase Signalling. Clin. Exp. Pharm. Physiol. 2011, 38, 239-246. [CrossRef]

58. Xia, H.-Q.; Pan, Y.; Peng, J.; Lu, G.-X. Over-Expression of MiR375 Reduces Glucose-Induced Insulin Secretion in Nit-1 Cells. Mol. Biol. Rep. 2011, 38, 3061-3065. [CrossRef] [PubMed]

59. Zhang, Z.; Peng, H.; Chen, J.; Chen, X.; Han, F.; Xu, X.; He, X.; Yan, N. MicroRNA-21 Protects from Mesangial Cell Proliferation Induced by Diabetic Nephropathy in Db/Db Mice. FEBS Lett. 2009, 583, 2009-2014. [CrossRef] [PubMed]

60. Huang, B.; Qin, W.; Zhao, B.; Shi, Y.; Yao, C.; Li, J.; Xiao, H.; Jin, Y. MicroRNA Expression Profiling in Diabetic GK Rat Model. Acta Biochim. Biophys. Sin. 2009, 41, 472-477. [CrossRef] [PubMed]

61. Lovis, P.; Roggli, E.; Laybutt, D.R.; Gattesco, S.; Yang, J.-Y.; Widmann, C.; Abderrahmani, A.; Regazzi, R. Alterations in MicroRNA Expression Contribute to Fatty Acid-Induced Pancreatic $\beta$-Cell Dysfunction. Diabetes 2008, 57, 2728-2736. [CrossRef] [PubMed]

62. Qi, H.; Yao, L.; Liu, Q. MicroRNA-96 Regulates Pancreatic $\beta$ Cell Function under the Pathological Condition of Diabetes Mellitus through Targeting Foxo1 and Sox6. Biochem. Biophys. Res. Commun. 2019, 519, 294-301. [CrossRef]

63. Lin, N.; Li, X.-Y.; Zhang, H.-M.; Yang, Z.; Su, Q. MicroRNA-199a-5p Mediates High Glucose-Induced Reactive Oxygen Species Production and Apoptosis in INS-1 Pancreatic $\beta$-Cells by Targeting SIRT1. Eur. Rev. Med. Pharm. Sci. 2017, 21, $1091-1098$.

64. Yu, C.-Y.; Yang, C.-Y.; Rui, Z.-L. MicroRNA-125b-5p Improves Pancreatic $\beta$-Cell Function through Inhibiting JNK Signaling Pathway by Targeting DACT1 in Mice with Type 2 Diabetes Mellitus. Life Sci. 2019, 224, 67-75. [CrossRef] [PubMed]

65. Plaisance, V.; Abderrahmani, A.; Perret-Menoud, V.; Jacquemin, P.; Lemaigre, F.; Regazzi, R. MicroRNA-9 Controls the Expression of Granuphilin/Slp4 and the Secretory Response of Insulin-Producing Cells. J. Biol. Chem. 2006, 281, 26932-26942. [CrossRef]

66. Al-Muhtaresh, H.A.; Al-Kafaji, G. Evaluation of Two-Diabetes Related MicroRNAs Suitability as Earlier Blood Biomarkers for Detecting Prediabetes and Type 2 Diabetes Mellitus. J. Clin. Med. 2018, 7, 12. [CrossRef] [PubMed]

67. Krek, A.; Grün, D.; Poy, M.N.; Wolf, R.; Rosenberg, L.; Epstein, E.J.; MacMenamin, P.; da Piedade, I.; Gunsalus, K.C.; Stoffel, M.; et al. Combinatorial MicroRNA Target Predictions. Nat. Genet. 2005, 37, 495-500. [CrossRef]

68. Baroukh, N.; Ravier, M.A.; Loder, M.K.; Hill, E.V.; Bounacer, A.; Scharfmann, R.; Rutter, G.A.; Van Obberghen, E. MicroRNA-124a Regulates Foxa2 Expression and Intracellular Signaling in Pancreatic Beta-Cell Lines. J. Biol. Chem. 2007, 282, 19575-19588. [CrossRef] [PubMed] 
69. Lovis, P.; Gattesco, S.; Regazzi, R. Regulation of the Expression of Components of the Exocytotic Machinery of Insulin-Secreting Cells by MicroRNAs. Biol. Chem. 2008, 389, 305-312. [CrossRef] [PubMed]

70. Chen, C.-Z.; Li, L.; Lodish, H.F.; Bartel, D.P. MicroRNAs Modulate Hematopoietic Lineage Differentiation. Science 2004, 303, 83-86. [CrossRef]

71. Yu, Y.; Du, H.; Wei, S.; Feng, L.; Li, J.; Yao, F.; Zhang, M.; Hatch, G.M.; Chen, L. Adipocyte-Derived Exosomal MiR-27a Induces Insulin Resistance in Skeletal Muscle Through Repression of PPAR $\gamma$. Theranostics 2018, 8, 2171-2188. [CrossRef]

72. Huang, F.; Zhu, P.; Wang, J.; Chen, J.; Lin, W. Postnatal Overfeeding Induces Hepatic MicroRNA-221 Expression and Impairs the PI3K/AKT Pathway in Adult Male Rats. Pediatr. Res. 2020. [CrossRef]

73. Liu, S.-X.; Zheng, F.; Xie, K.-L.; Xie, M.-R.; Jiang, L.-J.; Cai, Y. Exercise Reduces Insulin Resistance in Type 2 Diabetes Mellitus via Mediating the LncRNA MALAT1/MicroRNA-382-3p/Resistin Axis. Mol. Ther. Nucleic Acids 2019, 18, 34-44. [CrossRef] [PubMed]

74. Lu, H.; Buchan, R.J.; Cook, S.A. MicroRNA-223 Regulates Glut4 Expression and Cardiomyocyte Glucose Metabolism. Cardiovasc. Res. 2010, 86, 410-420. [CrossRef] [PubMed]

75. Wang, X.-Y.; Zhang, X.-Z.; Li, F.; Ji, Q.-R. MiR-128-3p Accelerates Cardiovascular Calcification and Insulin Resistance through ISL1-Dependent Wnt Pathway in Type 2 Diabetes Mellitus Rats. J. Cell. Physiol. 2019, 234, 4997-5010. [CrossRef]

76. Lin, X.; Qin, Y.; Jia, J.; Lin, T.; Lin, X.; Chen, L.; Zeng, H.; Han, Y.; Wu, L.; Huang, S.; et al. MiR-155 Enhances Insulin Sensitivity by Coordinated Regulation of Multiple Genes in Mice. PLoS Genet. 2016, 12, e1006308. [CrossRef]

77. De Candia, P.; Spinetti, G.; Specchia, C.; Sangalli, E.; Sala, L.L.; Uccellatore, A.; Lupini, S.; Genovese, S.; Matarese, G.; Ceriello, A. A Unique Plasma MicroRNA Profile Defines Type 2 Diabetes Progression. PLoS ONE 2017, 12, e0188980. [CrossRef] [PubMed]

78. Zhou, Y.; Wu, R.; Su, H.; Li, K.; Chen, C.; Xie, R. MiR-18a Increases Insulin Sensitivity by Inhibiting PTEN. Aging 2020, 13, 1357-1368. [CrossRef] [PubMed]

79. Latouche, C.; Natoli, A.; Reddy-Luthmoodoo, M.; Heywood, S.E.; Armitage, J.A.; Kingwell, B.A. MicroRNA-194 Modulates Glucose Metabolism and Its Skeletal Muscle Expression Is Reduced in Diabetes. PLoS ONE 2016, 11, e0155108. [CrossRef] [PubMed]

80. Zhu, Y.-L.; Chen, T.; Xiong, J.-L.; Wu, D.; Xi, Q.-Y.; Luo, J.-Y.; Sun, J.-J.; Zhang, Y.-L. MiR-146b Inhibits Glucose Consumption by Targeting IRS1 Gene in Porcine Primary Adipocytes. Int. J. Mol. Sci. 2018, 19, 783. [CrossRef]

81. Zhang, D.; Li, Y.; Yao, X.; Wang, H.; Zhao, L.; Jiang, H.; Yao, X.; Zhang, S.; Ye, C.; Liu, W.; et al. MiR-182 Regulates Metabolic Homeostasis by Modulating Glucose Utilization in Muscle. Cell Rep. 2016, 16, 757-768. [CrossRef] [PubMed]

82. Shi, Z.; Zhao, C.; Guo, X.; Ding, H.; Cui, Y.; Shen, R.; Liu, J. Differential Expression of MicroRNAs in Omental Adipose Tissue from Gestational Diabetes Mellitus Subjects Reveals MiR-222 as a Regulator of ER $\alpha$ Expression in Estrogen-Induced Insulin Resistance. Endocrinology 2014, 155, 1982-1990. [CrossRef]

83. Sadeghzadeh, S.; Dehghani Ashkezari, M.; Seifati, S.M.; Vahidi Mehrjardi, M.Y.; Dehghan Tezerjani, M.; Sadeghzadeh, S.; Ladan, S.A.B. Circulating MiR-15a and MiR-222 as Potential Biomarkers of Type 2 Diabetes. Diabetes Metab. Syndr. Obes. 2020, 13, 3461-3469. [CrossRef]

84. Xu, L.-N.; Yin, L.-H.; Jin, Y.; Qi, Y.; Han, X.; Xu, Y.-W.; Liu, K.-X.; Zhao, Y.-Y.; Peng, J.-Y. Effect and Possible Mechanisms of Dioscin on Ameliorating Metabolic Glycolipid Metabolic Disorder in Type-2-Diabetes. Phytomedicine 2020, 67, 153139. [CrossRef] [PubMed]

85. Dávalos, A.; Goedeke, L.; Smibert, P.; Ramírez, C.M.; Warrier, N.P.; Andreo, U.; Cirera-Salinas, D.; Rayner, K.; Suresh, U.; Pastor-Pareja, J.C.; et al. MiR-33a/b Contribute to the Regulation of Fatty Acid Metabolism and Insulin Signaling. Proc. Natl. Acad. Sci. USA 2011, 108, 9232-9237. [CrossRef]

86. Sun, L.; Li, X.; Li, G.; Dai, B.; Tan, W. Actinidia Chinensis Planch. Improves the Indices of Antioxidant and Anti-Inflammation Status of Type 2 Diabetes Mellitus by Activating Keap1 and Nrf2 via the Upregulation of MicroRNA-424. Oxid. Med. Cell. Longev. 2017, 2017, 7038789. [CrossRef]

87. Dehghani, M.; Aghaei Zarch, S.M.; Vahidi Mehrjardi, M.Y.; Nazari, M.; Babakhanzadeh, E.; Ghadimi, H.; Zeinali, F.; Talebi, M. Evaluation of MiR-181b and MiR-126-5p Expression Levels in T2DM Patients Compared to Healthy Individuals: Relationship with NF-KB Gene Expression. Endocrinol. Diabetes Nutr. 2020, 67, 454-460. [CrossRef] [PubMed]

88. Bravo-Egana, V.; Rosero, S.; Klein, D.; Jiang, Z.; Vargas, N.; Tsinoremas, N.; Doni, M.; Podetta, M.; Ricordi, C.; Molano, R.D.; et al. Inflammation-Mediated Regulation of MicroRNA Expression in Transplanted Pancreatic Islets. Available online: https://www. hindawi.com/journals/jtrans/2012/723614/ (accessed on 28 January 2021).

89. Ding, X.; Jian, T.; Wu, Y.; Zuo, Y.; Li, J.; Lv, H.; Ma, L.; Ren, B.; Zhao, L.; Li, W.; et al. Ellagic Acid Ameliorates Oxidative Stress and Insulin Resistance in High Glucose-Treated HepG2 Cells via MiR-223/Keap1-Nrf2 Pathway. Biomed. Pharm. 2019, 110 , 85-94. [CrossRef]

90. Giannella, A.; Radu, C.M.; Franco, L.; Campello, E.; Simioni, P.; Avogaro, A.; de Kreutzenberg, S.V.; Ceolotto, G. Circulating Levels and Characterization of Microparticles in Patients with Different Degrees of Glucose Tolerance. Cardiovasc. Diabetol 2017, 16, 118. [CrossRef] [PubMed]

91. Rubie, C.; Zimmer, J.; Lammert, F.; Gross, J.C.; Weber, S.N.; Kruse, B.; Halajda, B.; Wagner, M.; Wagenpfeil, S.; Glanemann, M. MicroRNA-496 and Mechanistic Target of Rapamycin Expression Are Associated with Type 2 Diabetes Mellitus and Obesity in Elderly People. Ann. Nutr. Metab. 2019, 74, 279-286. [CrossRef] [PubMed] 
92. Meerson, A.; Najjar, A.; Saad, E.; Sbeit, W.; Barhoum, M.; Assy, N. Sex Differences in Plasma MicroRNA Biomarkers of Early and Complicated Diabetes Mellitus in Israeli Arab and Jewish Patients. Noncoding RNA 2019, 5, 32. [CrossRef] [PubMed]

93. Nie, H.; Zhang, K.; Xu, J.; Liao, K.; Zhou, W.; Fu, Z. Combining Bioinformatics Techniques to Study Diabetes Biomarkers and Related Molecular Mechanisms. Front. Genet. 2020, 11. [CrossRef]

94. Feng, Y.; Ge, Y.; Wu, M.; Xie, Y.; Wang, M.; Chen, Y.; Shi, X. Long Non-Coding RNAs Regulate Inflammation in Diabetic Peripheral Neuropathy by Acting as CeRNAs Targeting MiR-146a-5p. Diabetes Metab. Syndr. Obes. 2020, 13, 413-422. [CrossRef]

95. Kokkinopoulou, I.; Maratou, E.; Mitrou, P.; Boutati, E.; Sideris, D.C.; Fragoulis, E.G.; Christodoulou, M.-I. Decreased Expression of MicroRNAs Targeting Type-2 Diabetes Susceptibility Genes in Peripheral Blood of Patients and Predisposed Individuals. Endocrine 2019, 66, 226-239. [CrossRef] [PubMed]

96. He, X.; Du, C.; Zou, Y.; Long, Y.; Huang, C.; Chen, F.; He, Y.; Zhou, X. Downregulation of MicroRNA-4463 Attenuates HighGlucose- and Hypoxia-Induced Endothelial Cell Injury by Targeting PNUTS. Cell. Physiol. Biochem. 2018, 49, 2073-2087. [CrossRef] [PubMed]

97. Eroglu, I.; Korkmaz, H.; Ozturk, K.H.; Sirin, F.B.; Sevik, S.; Afsar, B. New Risk Factors in Diabetic Nephropathy: MicroRNA-196-3p and MicroRNA-203. Minerva Endocrinol. 2020. [CrossRef]

98. Tang, Y.; Zheng, L.; Zhou, J.; Chen, Y.; Yang, L.; Deng, F.; Hu, Y. MiR-203-3p Participates in the Suppression of Diabetes-Associated Osteogenesis in the Jaw Bone through Targeting Smad1. Int. J. Mol. Med. 2018, 41, 1595-1607. [CrossRef]

99. Xiong, Y.; Chen, L.; Yan, C.; Zhou, W.; Endo, Y.; Liu, J.; Hu, L.; Hu, Y.; Mi, B.; Liu, G. Circulating Exosomal MiR-20b-5p Inhibition Restores Wnt9b Signaling and Reverses Diabetes-Associated Impaired Wound Healing. Small 2020, 16, e1904044. [CrossRef] [PubMed]

100. Blum, A.; Meerson, A.; Rohana, H.; Jabaly, H.; Nahul, N.; Celesh, D.; Romanenko, O.; Tamir, S. MicroRNA-423 May Regulate Diabetic Vasculopathy. Clin. Exp. Med. 2019, 19, 469-477. [CrossRef]

101. Jiang, Q.; Lyu, X.-M.; Yuan, Y.; Wang, L. Plasma MiR-21 Expression: An Indicator for the Severity of Type 2 Diabetes with Diabetic Retinopathy. Biosci. Rep. 2017, 37. [CrossRef] [PubMed]

102. Chen, Q.; Qiu, F.; Zhou, K.; Matlock, H.G.; Takahashi, Y.; Rajala, R.V.S.; Yang, Y.; Moran, E.; Ma, J.-X. Pathogenic Role of MicroRNA-21 in Diabetic Retinopathy Through Downregulation of PPAR $\alpha$. Diabetes 2017, 66, 1671-1682. [CrossRef] [PubMed]

103. Li, H.; Dai, B.; Fan, J.; Chen, C.; Nie, X.; Yin, Z.; Zhao, Y.; Zhang, X.; Wang, D.W. The Different Roles of MiRNA-92a-2-5p and Let-7b-5p in Mitochondrial Translation in Db/Db Mice. Mol. Ther. Nucleic Acids 2019, 17, 424-435. [CrossRef]

104. Greco, M.; Chiefari, E.; Accattato, F.; Corigliano, D.M.; Arcidiacono, B.; Mirabelli, M.; Liguori, R.; Brunetti, F.S.; Pullano, S.A.; Scorcia, V.; et al. MicroRNA-1281 as a Novel Circulating Biomarker in Patients With Diabetic Retinopathy. Front. Endocrinol. 2020, 11. [CrossRef]

105. Polina, E.R.; Oliveira, F.M.; Sbruzzi, R.C.; Crispim, D.; Canani, L.H.; Santos, K.G. Gene Polymorphism and Plasma Levels of MiR-155 in Diabetic Retinopathy. Endocr. Connect. 2019, 8, 1591-1599. [CrossRef] [PubMed]

106. Willeit, P.; Skroblin, P.; Moschen, A.R.; Yin, X.; Kaudewitz, D.; Zampetaki, A.; Barwari, T.; Whitehead, M.; Ramírez, C.M.; Goedeke, L.; et al. Circulating MicroRNA-122 Is Associated With the Risk of New-Onset Metabolic Syndrome and Type 2 Diabetes. Diabetes 2017, 66, 347-357. [CrossRef] [PubMed]

107. Giglio, R.V.; Nikolic, D.; Volti, G.L.; Stoian, A.P.; Banerjee, Y.; Magan-Fernandez, A.; Castellino, G.; Patti, A.M.; Chianetta, R.; Castracani, C.C.; et al. Liraglutide Increases Serum Levels of MicroRNA-27b, -130a and -210 in Patients with Type 2 Diabetes Mellitus: A Novel Epigenetic Effect. Metabolites 2020, 10, 391. [CrossRef] [PubMed]

108. Qun, L.; Wenda, X.; Weihong, S.; Jianyang, M.; Wei, C.; Fangzhou, L.; Zhenyao, X.; Pingjin, G. MiRNA-27b Modulates Endothelial Cell Angiogenesis by Directly Targeting Naa15 in Atherogenesis. Atherosclerosis 2016, 254, 184-192. [CrossRef]

109. Soares, R.J.; Cagnin, S.; Chemello, F.; Silvestrin, M.; Musaro, A.; De Pitta, C.; Lanfranchi, G.; Sandri, M. Involvement of MicroRNAs in the Regulation of Muscle Wasting during Catabolic Conditions. J. Biol. Chem. 2014, 289, 21909-21925. [CrossRef]

110. Moeez, S.; Riaz, S.; Masood, N.; Kanwal, N.; Arif, M.A.; Niazi, R.; Khalid, S. Evaluation of the Rs3088442 G>A SLC22A3 Gene Polymorphism and the Role of MicroRNA 147 in Groups of Adult Pakistani Populations with Type 2 Diabetes in Response to Metformin. Can. J. Diabetes 2019, 43, 128-135. [CrossRef]

111. Ye, M.; Li, D.; Yang, J.; Xie, J.; Yu, F.; Ma, Y.; Zhu, X.; Zhao, J.; Lv, Z. MicroRNA-130a Targets MAP3K12 to Modulate Diabetic Endothelial Progenitor Cell Function. Cell. Physiol. Biochem. 2015, 36, 712-726. [CrossRef] [PubMed]

112. Tian, F.; Tang, P.; Sun, Z.; Zhang, R.; Zhu, D.; He, J.; Liao, J.; Wan, Q.; Shen, J. MiR-210 in Exosomes Derived from Macrophages under High Glucose Promotes Mouse Diabetic Obesity Pathogenesis by Suppressing NDUFA4 Expression. J. Diabetes Res. 2020, 2020, 6894684. [CrossRef]

113. DeFronzo, R.A.; Ferrannini, E.; Groop, L.; Henry, R.R.; Herman, W.H.; Holst, J.J.; Hu, F.B.; Kahn, C.R.; Raz, I.; Shulman, G.I.; et al. Type 2 Diabetes Mellitus. Nat. Rev. Dis. Primers 2015, 1, 1-22. [CrossRef]

114. Seyhan, A.A.; Nunez Lopez, Y.O.; Xie, H.; Yi, F.; Mathews, C.; Pasarica, M.; Pratley, R.E. Pancreas-Enriched MiRNAs Are Altered in the Circulation of Subjects with Diabetes: A Pilot Cross-Sectional Study. Sci. Rep. 2016, 6, 31479. [CrossRef]

115. Xie, Y.; Chu, A.; Feng, Y.; Chen, L.; Shao, Y.; Luo, Q.; Deng, X.; Wu, M.; Shi, X.; Chen, Y. MicroRNA-146a: A Comprehensive Indicator of Inflammation and Oxidative Stress Status Induced in the Brain of Chronic T2DM Rats. Front. Pharm. 2018, 9, 478. [CrossRef] 
116. Yin, L.; Zhang, T.; Wei, Y.; Cai, W.-J.; Feng, G.; Chang, X.-Y.; Sun, K. Epigenetic Regulation of MicroRNA-375 and Its Role as DNA Epigenetic Marker of Type 2 Diabetes Mellitus in Chinese Han Population. Int. J. Clin. Exp. Pathol. 2017, 10, 11986-11994. [PubMed]

117. Chang, X.; Li, S.; Li, J.; Yin, L.; Zhou, T.; Zhang, C.; Chen, X.; Sun, K. Ethnic Differences in MicroRNA-375 Expression Level and DNA Methylation Status in Type 2 Diabetes of Han and Kazak Populations. J. Diabetes Res. 2014, 2014, 761938. [CrossRef]

118. Kulkarni, M.; Leszczynska, A.; Wei, G.; Winkler, M.A.; Tang, J.; Funari, V.A.; Deng, N.; Liu, Z.; Punj, V.; Deng, S.X.; et al. Genome-Wide Analysis Suggests a Differential MicroRNA Signature Associated with Normal and Diabetic Human Corneal Limbus. Sci. Rep. 2017, 7, 3448. [CrossRef] [PubMed]

119. Feng, Y.; Chen, L.; Luo, Q.; Wu, M.; Chen, Y.; Shi, X. Involvement of MicroRNA-146a in Diabetic Peripheral Neuropathy through the Regulation of Inflammation. Drug Des. Dev. Ther. 2018, 12, 171-177. [CrossRef]

120. Sangalli, E.; Tagliabue, E.; Sala, L.L.; Prattichizzo, F.; Uccellatore, A.; Spada, D.; Lorino, F.; de Candia, P.; Lupini, S.; Cantone, L.; et al. Circulating MicroRNA-15a Associates With Retinal Damage in Patients with Early Stage Type 2 Diabetes. Front. Endocrinol. 2020, 11, 254. [CrossRef]

121. Kaidonis, G.; Gillies, M.C.; Abhary, S.; Liu, E.; Essex, R.W.; Chang, J.H.; Pal, B.; Sivaprasad, S.; Pefkianaki, M.; Daniell, M.; et al. A Single-Nucleotide Polymorphism in the MicroRNA-146a Gene Is Associated with Diabetic Nephropathy and Sight-Threatening Diabetic Retinopathy in Caucasian Patients. Acta Diabetol. 2016, 53, 643-650. [CrossRef]

122. Kajimoto, K.; Naraba, H.; Iwai, N. MicroRNA and 3T3-L1 Pre-Adipocyte Differentiation. RNA 2006, 12, 1626-1632. [CrossRef] [PubMed]

123. Wang, Y.; Wang, D.-S.; Cheng, Y.-S.; Jia, B.-L.; Yu, G.; Yin, X.-Q.; Wang, Y. Expression of MicroRNA-448 and SIRT1 and Prognosis of Obese Type 2 Diabetic Mellitus Patients After Laparoscopic Bariatric Surgery. Cell. Physiol. Biochem. 2018, 45, 935-950. [CrossRef] [PubMed]

124. Coskun, Z.M.; Beydogan, A.B.; Bolkent, S. Changes in the Expression Levels of CB1 and GLP-1R MRNAs and MicroRNAs 33a and 122 in the Liver of Type 2 Diabetic Rats Treated with Ghrelin. J. Biochem. Mol. Toxicol. 2019, 33, e22388. [CrossRef] [PubMed]

125. Peng, Y.; Croce, C.M. The Role of MicroRNAs in Human Cancer. Signal. Transduct. Target. Ther. 2016, 1, 15004. [CrossRef] [PubMed]

126. Ying, S.-Y.; Chang, C.P.; Lin, S.-L. Intron-Mediated RNA Interference, Intronic MicroRNAs, and Applications. Methods Mol. Biol. 2010, 629, 205-237. [CrossRef]

127. Shimomura, A.; Shiino, S.; Kawauchi, J.; Takizawa, S.; Sakamoto, H.; Matsuzaki, J.; Ono, M.; Takeshita, F.; Niida, S.; Shimizu, C.; et al. Novel Combination of Serum MicroRNA for Detecting Breast Cancer in the Early Stage. Cancer Sci. 2016, 107, 326-334. [CrossRef]

128. Amini, S.; Abak, A.; Estiar, M.A.; Montazeri, V.; Abhari, A.; Sakhinia, E. Expression Analysis of MicroRNA-222 in Breast Cancer. Clin. Lab. 2018, 64, 491-496. [CrossRef]

129. Assiri, A.A.; Mourad, N.; Shao, M.; Kiel, P.; Liu, W.; Skaar, T.C.; Overholser, B.R. MicroRNA 362-3p Reduces HERG-Related Current and Inhibits Breast Cancer Cells Proliferation. Cancer Genom. Proteom. 2019, 16, 433-442. [CrossRef]

130. Zhang, J.; Kong, X.; Shi, Q.; Zhao, B. MicroRNA-383-5p Acts as a Potential Prognostic Biomarker and an Inhibitor of Tumor Cell Proliferation, Migration, and Invasion in Breast Cancer. Cancer Biomark. 2020, 27, 423-432. [CrossRef] [PubMed]

131. Wang, S.; Li, H.; Wang, J.; Wang, D.; Yao, A.; Li, Q. Prognostic and Biological Significance of MicroRNA-127 Expression in Human Breast Cancer. Dis. Markers 2014, 2014, 401986. [CrossRef]

132. Sun, W.-J.; Zhang, Y.-N.; Xue, P. MiR-186 Inhibits Proliferation, Migration, and Epithelial-Mesenchymal Transition in Breast Cancer Cells by Targeting Twist1. J. Cell. Biochem. 2019, 120, 10001-10009. [CrossRef] [PubMed]

133. Xiang, Y.; Tian, Q.; Guan, L.; Niu, S. The Dual Role of MiR-186 in Cancers: Oncomir Battling with Tumor Suppressor MiRNA. Front. Oncol. 2020, 10. [CrossRef] [PubMed]

134. Liu, Q.; Peng, F.; Chen, J. The Role of Exosomal MicroRNAs in the Tumor Microenvironment of Breast Cancer. Int. J. Mol. Sci. 2019, 20, 3884. [CrossRef]

135. Fan, L.-Y.; Shi, K.-Y.; Xu, D.; Ren, L.-P.; Yang, P.; Zhang, L.; Wang, F.; Shao, G.-L. LncRNA GIHCG Regulates MicroRNA-1281 and Promotes Malignant Progression of Breast Cancer. Eur. Rev. Med. Pharm. Sci. 2019, 23, 10842-10850. [CrossRef]

136. Khalighfard, S.; Alizadeh, A.M.; Irani, S.; Omranipour, R. Plasma MiR-21, MiR-155, MiR-10b, and Let-7a as the Potential Biomarkers for the Monitoring of Breast Cancer Patients. Sci. Rep. 2018, 8, 17981. [CrossRef]

137. Stahlhut Espinosa, C.E.; Slack, F.J. The Role of MicroRNAs in Cancer. Yale J. Biol. Med. 2006, 79, 131-140.

138. Jiang, J.; Yang, X.; He, X.; Ma, W.; Wang, J.; Zhou, Q.; Li, M.; Yu, S. MicroRNA-449b-5p Suppresses the Growth and Invasion of Breast Cancer Cells via Inhibiting CREPT-Mediated Wnt/ $\beta$-Catenin Signaling. Chem. Biol. Interact. 2019, 302, 74-82. [CrossRef] [PubMed]

139. Xie, Q.; Wang, S.; Zhao, Y.; Zhang, Z.; Qin, C.; Yang, X. MicroRNA-216a Suppresses the Proliferation and Migration of Human Breast Cancer Cells via the Wnt/ $\beta$-Catenin Signaling Pathway. Oncol. Rep. 2019, 41, 2647-2656. [CrossRef]

140. Gao, J.; Yu, S.-R.; Yuan, Y.; Zhang, L.-L.; Lu, J.-W.; Feng, J.-F.; Hu, S.-N. MicroRNA-590-5p Functions as a Tumor Suppressor in Breast Cancer Conferring Inhibitory Effects on Cell Migration, Invasion, and Epithelial-Mesenchymal Transition by Downregulating the Wnt- $\beta$-Catenin Signaling Pathway. J. Cell. Physiol. 2019, 234, 1827-1841. [CrossRef]

141. Zhao, W.; Geng, D.; Li, S.; Chen, Z.; Sun, M. LncRNA HOTAIR Influences Cell Growth, Migration, Invasion, and Apoptosis via the MiR-20a-5p/HMGA2 Axis in Breast Cancer. Cancer Med. 2018, 7, 842-855. [CrossRef] [PubMed] 
142. Zhuang, C.; Yuan, Y.; Song, T.; Wang, H.; Huang, L.; Luo, X.; He, H.; Huo, L.; Zhou, H.; Wang, N.; et al. MiR-219a-5p Inhibits Breast Cancer Cell Migration and Epithelial-Mesenchymal Transition by Targeting Myocardin-Related Transcription Factor A. Acta Biochim. Biophys. Sin. 2017, 49, 1112-1121. [CrossRef] [PubMed]

143. Lu, Y.; Qin, T.; Li, J.; Wang, L.; Zhang, Q.; Jiang, Z.; Mao, J. MicroRNA-140-5p Inhibits Invasion and Angiogenesis through Targeting VEGF-A in Breast Cancer. Cancer Gene Ther. 2017, 24, 386-392. [CrossRef]

144. Hu, J.; Guo, P.; Zhang, Y.; Huang, Z.; Chen, B. MicroRNA-322 Regulates the Growth, Chemosensitivity, Migration and Invasion of Breast Cancer Cells by Targeting NF-KB1. J. BU ON 2020, 25, 152-158.

145. Fan, X.; Fang, X.; Liu, G.; Xiong, Q.; Li, Z.; Zhou, W. MicroRNA-204 Inhibits the Proliferation and Metastasis of Breast Cancer Cells by Targeting PI3K/AKT Pathway. J. BU ON 2019, 24, 1054-1059.

146. Yang, Y.; Jiang, Z.; Ma, N.; Wang, B.; Liu, J.; Zhang, L.; Gu, L. MicroRNA-223 Targeting STIM1 Inhibits the Biological Behavior of Breast Cancer. Cell. Physiol. Biochem. 2018, 45, 856-866. [CrossRef] [PubMed]

147. Lin, Y.; Liu, A.Y.; Fan, C.; Zheng, H.; Li, Y.; Zhang, C.; Wu, S.; Yu, D.; Huang, Z.; Liu, F.; et al. MicroRNA-33b Inhibits Breast Cancer Metastasis by Targeting HMGA2, SALL4 and Twist1. Sci. Rep. 2015, 5, 9995. [CrossRef] [PubMed]

148. Bouyssou, J.M.C.; Manier, S.; Huynh, D.; Issa, S.; Roccaro, A.M.; Ghobrial, I.M. Regulation of MicroRNAs in Cancer Metastasis. Biochim. Biophys. Acta 2014, 1845, 255-265. [CrossRef]

149. Yan, X.; Chen, X.; Liang, H.; Deng, T.; Chen, W.; Zhang, S.; Liu, M.; Gao, X.; Liu, Y.; Zhao, C.; et al. MiR-143 and MiR-145 Synergistically Regulate ERBB3 to Suppress Cell Proliferation and Invasion in Breast Cancer. Mol. Cancer 2014, 13, 220. [CrossRef] [PubMed]

150. Lee, J.-W.; Guan, W.; Han, S.; Hong, D.-K.; Kim, L.-S.; Kim, H. MicroRNA-708-3p Mediates Metastasis and Chemoresistance through Inhibition of Epithelial-to-Mesenchymal Transition in Breast Cancer. Cancer Sci. 2018, 109, 1404-1413. [CrossRef] [PubMed]

151. Yan, J.; Xu, Y.; Wang, H.; Du, T.; Chen, H. MicroRNA-503 Inhibits the Proliferation and Invasion of Breast Cancer Cells via Targeting Insulin-like Growth Factor 1 Receptor. Mol. Med. Rep. 2017, 16, 1707-1714. [CrossRef] [PubMed]

152. Li, Q.; Ren, P.; Shi, P.; Chen, Y.; Xiang, F.; Zhang, L.; Wang, J.; Lv, Q.; Xie, M. MicroRNA-148a Promotes Apoptosis and Suppresses Growth of Breast Cancer Cells by Targeting B-Cell Lymphoma 2. Anticancer Drugs 2017, 28, 588-595. [CrossRef]

153. Huang, Z.-M.; Ge, H.-F.; Yang, C.-C.; Cai, Y.; Chen, Z.; Tian, W.-Z.; Tao, J.-L. MicroRNA-26a-5p Inhibits Breast Cancer Cell Growth by Suppressing RNF6 Expression. Kaohsiung J. Med. Sci. 2019, 35, 467-473. [CrossRef]

154. Du, Y.; Shen, L.; Zhang, W.; Ding, R.; Li, Q.; Li, S.; Zhang, H. Functional Analyses of MicroRNA-326 in Breast Cancer Development. Biosci. Rep. 2019, 39. [CrossRef] [PubMed]

155. Xia, W.; Gong, D.; Qin, X.; Cai, Z. MicroRNA-671-3p suppresses proliferation and invasion of breast cancer cells by targeting DEPTOR. Nan Fang Yi Ke Da Xue Xue Bao 2020, 40, 42-48. [CrossRef] [PubMed]

156. Yu, X.-Y.; Tian, J.-R.; Yang, D.; Tan, H.-R. TATDN1 Promotes the Development and Progression of Breast Cancer by Targeting MicroRNA-140-3p. Eur. Rev. Med. Pharm. Sci. 2019, 23, 5293-5300. [CrossRef]

157. Chen, C.; Liu, X.; Chen, C.; Chen, Q.; Dong, Y.; Hou, B. Clinical Significance of Let-7a-5p and MiR-21-5p in Patients with Breast Cancer. Ann. Clin. Lab. Sci. 2019, 49, 302-308.

158. Liu, C.; Chen, Z.; Fang, M.; Qiao, Y. MicroRNA Let-7a Inhibits Proliferation of Breast Cancer Cell by Downregulating USP32 Expression. Transl. Cancer Res. 2019, 8. [CrossRef]

159. Wang, B.; Wang, H.; Yang, Z. MiR-122 Inhibits Cell Proliferation and Tumorigenesis of Breast Cancer by Targeting IGF1R. PLoS ONE 2012, 7, e47053. [CrossRef]

160. ZHANG, Y.; ZHANG, H.; LIU, Z. MicroRNA-147 Suppresses Proliferation, Invasion and Migration through the AKT/MTOR Signaling Pathway in Breast Cancer. Oncol. Lett. 2016, 11, 405-410. [CrossRef]

161. Sachdeva, M.; Mo, Y.-Y. MicroRNA-145 Suppresses Cell Invasion and Metastasis by Directly Targeting Mucin 1. Cancer Res. 2010, 70, 378-387. [CrossRef] [PubMed]

162. Wang, H.; Li, X.; Li, T.; Wang, L.; Wu, X.; Liu, J.; Xu, Y.; Wei, W. Multiple Roles of MicroRNA-146a in Immune Responses and Hepatocellular Carcinoma. Oncol. Lett. 2019, 18, 5033-5042. [CrossRef]

163. Wang, H.; Tan, Z.; Hu, H.; Liu, H.; Wu, T.; Zheng, C.; Wang, X.; Luo, Z.; Wang, J.; Liu, S.; et al. MicroRNA-21 Promotes Breast Cancer Proliferation and Metastasis by Targeting LZTFL1. BMC Cancer 2019, 19, 738. [CrossRef]

164. Huang, L.; Liu, X. MicroRNA-370 Promotes Cell Growth by Targeting WNK2 in Breast Cancer. DNA Cell Biol. 2019, 38, 501-509. [CrossRef]

165. Li, X.; Zeng, Z.; Wang, J.; Wu, Y.; Chen, W.; Zheng, L.; Xi, T.; Wang, A.; Lu, Y. MicroRNA-9 and Breast Cancer. Biomed. Pharm. 2020, 122, 109687. [CrossRef]

166. Eissa, S.; Matboli, M.; Sharawy, A.; El-Sharkawi, F. Prognostic and Biological Significance of MicroRNA-221 in Breast Cancer. Gene 2015, 574, 163-167. [CrossRef]

167. Li, B.; Lu, Y.; Yu, L.; Han, X.; Wang, H.; Mao, J.; Shen, J.; Wang, B.; Tang, J.; Li, C.; et al. MiR-221/222 Promote Cancer Stem-like Cell Properties and Tumor Growth of Breast Cancer via Targeting PTEN and Sustained Akt/NF-KB/COX-2 Activation. Chem. Biol. Interact. 2017, 277, 33-42. [CrossRef]

168. Li, B.; Lu, Y.; Wang, H.; Han, X.; Mao, J.; Li, J.; Yu, L.; Wang, B.; Fan, S.; Yu, X.; et al. MiR-221/222 Enhance the Tumorigenicity of Human Breast Cancer Stem Cells via Modulation of PTEN/Akt Pathway. Biomed. Pharm. 2016, 79, 93-101. [CrossRef] 
169. Pan, Y.; Li, J.; Zhang, Y.; Wang, N.; Liang, H.; Liu, Y.; Zhang, C.-Y.; Zen, K.; Gu, H. Slug-Upregulated MiR-221 Promotes Breast Cancer Progression through Suppressing E-Cadherin Expression. Sci. Rep. 2016, 6, 25798. [CrossRef] [PubMed]

170. Liu, J.-H.; Yang, Y.; Song, Q.; Li, J.B. MicroRNA-155regulates the Proliferation and Metastasis of Human Breast Cancers by Targeting MAPK7. J. BU ON 2019, 24, 1075-1080.

171. Wang, Y.; Liu, Z.; Shen, J. MicroRNA-421-Targeted PDCD4 Regulates Breast Cancer Cell Proliferation. Int. J. Mol. Med. 2019, 43, 267-275. [CrossRef] [PubMed]

172. Liu, C.; Song, Y.-H.; Mao, Y.; Wang, H.-B.; Nie, G. MiRNA-106a Promotes Breast Cancer Progression by Regulating DAX-1. Eur. Rev. Med. Pharm. Sci. 2019, 23, 1574-1583. [CrossRef]

173. Petrovic, N.; Davidovic, R.; Bajic, V.; Obradovic, M.; Isenovic, R.E. MicroRNA in Breast Cancer: The Association with BRCA1/2. Cancer Biomark. 2017, 19, 119-128. [CrossRef] [PubMed]

174. Shin, B.; Feser, R.; Nault, B.; Hunter, S.; Maiti, S.; Ugwuagbo, K.C.; Majumder, M. MiR526b and MiR655 Induce Oxidative Stress in Breast Cancer. Int. J. Mol. Sci. 2019, 20, 4039. [CrossRef]

175. Yu, H.; Xing, H.; Han, W.; Wang, Y.; Qi, T.; Song, C.; Xu, Z.; Li, H.; Huang, Y. MicroRNA-409-5p Is Upregulated in Breast Cancer and Its Downregulation Inhibits Cancer Development through Downstream Target of RSU1. Tumour Biol. 2017, 39, 1010428317701647. [CrossRef]

176. Han, M.; Wang, Y.; Guo, G.; Li, L.; Dou, D.; Ge, X.; Lv, P.; Wang, F.; Gu, Y. MicroRNA-30d Mediated Breast Cancer Invasion, Migration, and EMT by Targeting KLF11 and Activating STAT3 Pathway. J. Cell. Biochem. 2018, 119, 8138-8145. [CrossRef]

177. Setijono, S.R.; Park, M.; Kim, G.; Kim, Y.; Cho, K.W.; Song, S.J. MiR-218 and MiR-129 Regulate Breast Cancer Progression by Targeting Lamins. Biochem. Biophys. Res. Commun. 2018, 496, 826-833. [CrossRef] [PubMed]

178. Niedźwiecki, S.; Piekarski, J.; Szymańska, B.; Pawłowska, Z.; Jeziorski, A. Serum Levels of Circulating MiRNA-21, MiRNA-10b and MiRNA-200c in Triple-Negative Breast Cancer Patients. Ginekol. Pol. 2018, 89, 415-420. [CrossRef]

179. Hong, H.; Yu, H.; Yuan, J.; Guo, C.; Cao, H.; Li, W.; Xiao, C. MicroRNA-200b Impacts Breast Cancer Cell Migration and Invasion by Regulating Ezrin-Radixin-Moesin. Med. Sci. Monit. 2016, 22, 1946-1952. [CrossRef] [PubMed]

180. Yao, Y.; Hu, J.; Shen, Z.; Yao, R.; Liu, S.; Li, Y.; Cong, H.; Wang, X.; Qiu, W.; Yue, L. MiR-200b Expression in Breast Cancer: A Prognostic Marker and Act on Cell Proliferation and Apoptosis by Targeting Sp1. J. Cell. Mol. Med. 2015, 19, 760-769. [CrossRef] [PubMed]

181. Shao, X.; Huang, P.; Shi, L.; Lei, L.; Cao, W.; Chen, Z.; Wang, X.; Zheng, Y. MicroRNA and LncRNA Expression Profiles in Human Estrogen Receptor Positive Breast Cancer. Clin. Lab. 2019, 65. [CrossRef]

182. Kang, P.-C.; Leng, K.-M.; Liu, Y.-P.; Liu, Y.; Xu, Y.; Qin, W.; Gao, J.-J.; Wang, Z.-D.; Tai, S.; Zhong, X.-Y.; et al. MiR-191 Inhibition Induces Apoptosis Through Reactivating Secreted Frizzled-Related Protein-1 in Cholangiocarcinoma. CPB 2018, 49, $1933-1942$. [CrossRef]

183. Zhang, X.; Zhao, H.; Zhang, Y.; Yang, X.; Zhang, J.; Yi, M.; Zhang, C. The MicroRNA-382-5p/MXD1 Axis Relates to Breast Cancer Progression and Promotes Cell Malignant Phenotypes. J. Surg. Res. 2020, 246, 442-449. [CrossRef]

184. Liang, Y.-K.; Lin, H.-Y.; Dou, X.-W.; Chen, M.; Wei, X.-L.; Zhang, Y.-Q.; Wu, Y.; Chen, C.-F.; Bai, J.-W.; Xiao, Y.-S.; et al. MiR-221/222 Promote Epithelial-Mesenchymal Transition by Targeting Notch3 in Breast Cancer Cell Lines. NPJ Breast Cancer 2018, 4, 1-9. [CrossRef]

185. Zhao, J.-J.; Lin, J.; Yang, H.; Kong, W.; He, L.; Ma, X.; Coppola, D.; Cheng, J.Q. MicroRNA-221/222 Negatively Regulates Estrogen Receptor Alpha and Is Associated with Tamoxifen Resistance in Breast Cancer. J. Biol. Chem. 2008, 283, 31079-31086. [CrossRef]

186. Liu, J.; Zhou, Y.; Shi, Z.; Hu, Y.; Meng, T.; Zhang, X.; Zhang, S.; Zhang, J. MicroRNA-497 Modulates Breast Cancer Cell Proliferation, Invasion, and Survival by Targeting SMAD7. DNA Cell Biol. 2016, 35, 521-529. [CrossRef]

187. Shi, Y.; Zhang, Y.; Ran, F.; Liu, J.; Lin, J.; Hao, X.; Ding, L.; Ye, Q. Let-7a-5p Inhibits Triple-Negative Breast Tumor Growth and Metastasis through GLUT12-Mediated Warburg Effect. Cancer Lett. 2020, 495, 53-65. [CrossRef] [PubMed]

188. Krutilina, R.; Sun, W.; Sethuraman, A.; Brown, M.; Seagroves, T.N.; Pfeffer, L.M.; Ignatova, T.; Fan, M. MicroRNA-18a Inhibits Hypoxia-Inducible Factor $1 \alpha$ Activity and Lung Metastasis in Basal Breast Cancers. Breast Cancer Res. 2014, 16, R78. [CrossRef]

189. Luengo-Gil, G.; García-Martínez, E.; Chaves-Benito, A.; Conesa-Zamora, P.; Navarro-Manzano, E.; González-Billalabeitia, E.; García-Garre, E.; Martínez-Carrasco, A.; Vicente, V.; Ayala de la Peña, F. Clinical and Biological Impact of MiR-18a Expression in Breast Cancer after Neoadjuvant Chemotherapy. Cell. Oncol. 2019, 42, 627-644. [CrossRef] [PubMed]

190. Sha, L.-Y.; Zhang, Y.; Wang, W.; Sui, X.; Liu, S.-K.; Wang, T.; Zhang, H. MiR-18a Upregulation Decreases Dicer Expression and Confers Paclitaxel Resistance in Triple Negative Breast Cancer. Eur. Rev. Med. Pharm. Sci. 2016, 20, 2201-2208.

191. Hong, Z.; Hong, C.; Ma, B.; Wang, Q.; Zhang, X.; Li, L.; Wang, C.; Chen, D. MicroRNA-126-3p Inhibits the Proliferation, Migration, Invasion, and Angiogenesis of Triple-negative Breast Cancer Cells by Targeting RGS3. Oncol. Rep. 2019, 42, 1569-1579. [CrossRef] [PubMed]

192. Ben Gacem, R.; Ben Abdelkrim, O.; Ziadi, S.; Ben Dhiab, M.; Trimeche, M. Methylation of MiR-124a-1, MiR-124a-2, and MiR-124a-3 Genes Correlates with Aggressive and Advanced Breast Cancer Disease. Tumour Biol. 2014, 35, 4047-4056. [CrossRef]

193. Ren, G.-B.; Wang, L.; Zhang, F.-H.; Meng, X.-R.; Mao, Z.-P. Study on the Relationship between MiR-520g and the Development of Breast Cancer. Eur. Rev. Med. Pharm. Sci. 2016, 20, 657-663.

194. Wang, Y.-W.; Zhao, S.; Yuan, X.-Y.; Liu, Y.; Zhang, K.; Wang, J.; Zhu, J.; Ma, R. MiR-4732-5p Promotes Breast Cancer Progression by Targeting TSPAN13. J. Cell. Mol. Med. 2019, 23, 2549-2557. [CrossRef] [PubMed] 
195. Jiang, H.; Cheng, L.; Hu, P.; Liu, R. MicroRNA-663b Mediates TAM Resistance in Breast Cancer by Modulating TP73 Expression. Mol. Med. Rep. 2018, 18, 1120-1126. [CrossRef]

196. Uhr, K.; Sieuwerts, A.M.; de Weerd, V.; Smid, M.; Hammerl, D.; Foekens, J.A.; Martens, J.W.M. Association of MicroRNA-7 and Its Binding Partner CDR1-AS with the Prognosis and Prediction of 1st-Line Tamoxifen Therapy in Breast Cancer. Sci. Rep. 2018, 8, 9657. [CrossRef] [PubMed]

197. Li, M.; Pan, M.; Wang, J.; You, C.; Zhao, F.; Zheng, D.; Guo, M.; Xu, H.; Wu, D.; Wang, L.; et al. MiR-7 Reduces Breast Cancer Stem Cell Metastasis via Inhibiting RELA to Decrease ESAM Expression. Mol. Ther. Oncolytics 2020, 18, 70-82. [CrossRef]

198. Zhang, H.; Cai, K.; Wang, J.; Wang, X.; Cheng, K.; Shi, F.; Jiang, L.; Zhang, Y.; Dou, J. MiR-7, Inhibited Indirectly by LincRNA HOTAIR, Directly Inhibits SETDB1 and Reverses the EMT of Breast Cancer Stem Cells by Downregulating the STAT3 Pathway. Stem Cells 2014, 32, 2858-2868. [CrossRef]

199. Zhao, W.; Zhang, X.; Zhou, Z.; Sun, B.; Gu, W.; Liu, J.; Zhang, H. Liraglutide Inhibits the Proliferation and Promotes the Apoptosis of MCF-7 Human Breast Cancer Cells through Downregulation of MicroRNA-27a Expression. Mol. Med. Rep. 2018, 17, 5202-5212. [CrossRef] [PubMed]

200. Zhou, L.; Zhao, L.-C.; Jiang, N.; Wang, X.-L.; Zhou, X.-N.; Luo, X.-L.; Ren, J. MicroRNA MiR-590-5p Inhibits Breast Cancer Cell Stemness and Metastasis by Targeting SOX2. Eur. Rev. Med. Pharm. Sci. 2017, 21, 87-94.

201. Wei, Y.-T.; Guo, D.-W.; Hou, X.-Z.; Jiang, D.-Q. MiRNA-223 Suppresses FOXO1 and Functions as a Potential Tumor Marker in Breast Cancer. Cell. Mol. Biol. 2017, 63, 113-118. [CrossRef] [PubMed]

202. Soheilyfar, S.; Velashjerdi, Z.; Sayed Hajizadeh, Y.; Fathi Maroufi, N.; Amini, Z.; Khorrami, A.; Haj Azimian, S.; Isazadeh, A.; Taefehshokr, S.; Taefehshokr, N. In Vivo and in Vitro Impact of MiR-31 and MiR-143 on the Suppression of Metastasis and Invasion in Breast Cancer. J. BU ON 2018, 23, 1290-1296.

203. Ye, D.; Shen, Z.; Zhou, S. Function of MicroRNA-145 and Mechanisms Underlying Its Role in Malignant Tumor Diagnosis and Treatment. Cancer Manag. Res. 2019, 11, 969-979. [CrossRef]

204. Yang, C.-Y.; Zhang, F.-X.; He, J.-N.; Wang, S.-Q. CircRNA_100876 Promote Proliferation and Metastasis of Breast Cancer Cells through Adsorbing MicroRNA-361-3p in a Sponge Form. Eur. Rev. Med. Pharm. Sci. 2019, 23, 6962-6970. [CrossRef]

205. Cheng, C.-W.; Yu, J.-C.; Hsieh, Y.-H.; Liao, W.-L.; Shieh, J.-C.; Yao, C.-C.; Lee, H.-J.; Chen, P.-M.; Wu, P.-E.; Shen, C.-Y. Increased Cellular Levels of MicroRNA-9 and MicroRNA-221 Correlate with Cancer Stemness and Predict Poor Outcome in Human Breast Cancer. Cell. Physiol. Biochem. 2018, 48, 2205-2218. [CrossRef]

206. Dvinge, H.; Git, A.; Gräf, S.; Salmon-Divon, M.; Curtis, C.; Sottoriva, A.; Zhao, Y.; Hirst, M.; Armisen, J.; Miska, E.A.; et al. The Shaping and Functional Consequences of the MicroRNA Landscape in Breast Cancer. Nature 2013, 497, 378-382. [CrossRef]

207. Nassirpour, R.; Mehta, P.P.; Yin, M.-J. MiR-122 Regulates Tumorigenesis in Hepatocellular Carcinoma by Targeting AKT3. PLoS ONE 2013, 8, e79655. [CrossRef] [PubMed]

208. Liu, H.-T.; Xu, Y.-T.; Li, H.-Y.; Zhao, J.; Zhai, H.-Y.; Chen, Y. Loss of MicroRNA-145 Expression Is Involved in the Development and Prognosis of Breast Cancer Complicated by Type 2 Diabetes Mellitus. Int. J. Biol. Markers 2016, 31, e368-e374. [CrossRef] [PubMed]

209. FunRich: Functional Enrichment Analysis Tool: Home. Available online: http:/ / www.funrich.org/ (accessed on 27 December 2020).

210. Zhang, S.; Guo, L.-J.; Zhang, G.; Wang, L.-L.; Hao, S.; Gao, B.; Jiang, Y.; Tian, W.-G.; Cao, X.-E.; Luo, D.-L. Roles of MicroRNA-124a and MicroRNA-30d in Breast Cancer Patients with Type 2 Diabetes Mellitus. Tumour Biol. 2016, 37, 11057-11063. [CrossRef]

211. Dehwah, M.A.S.; Xu, A.; Huang, Q. MicroRNAs and Type 2 Diabetes/Obesity. J. Genet. Genom. 2012, 39, 11-18. [CrossRef]

212. Han, Y.-L.; Cao, X.-E.; Wang, J.-X.; Dong, C.-L.; Chen, H.-T. Correlations of MicroRNA-124a and MicroRNA-30d with Clinicopathological Features of Breast Cancer Patients with Type 2 Diabetes Mellitus. Springerplus 2016, 5, 2107. [CrossRef]

213. Mao, Q.; Unadkat, J.D. Role of the Breast Cancer Resistance Protein (BCRP/ABCG2) in Drug Transport-An Update. AAPS J. 2015, 17, 65-82. [CrossRef]

214. Dentelli, P.; Traversa, M.; Rosso, A.; Togliatto, G.; Olgasi, C.; Marchiò, C.; Provero, P.; Lembo, A.; Bon, G.; Annaratone, L.; et al. MiR-221/222 Control Luminal Breast Cancer Tumor Progression by Regulating Different Targets. Cell Cycle 2014, 13, $1811-1826$. [CrossRef]

215. Li, M.Y.; Pan, S.R.; Qiu, A.Y. Roles of MicroRNA-221/222 in Type 2 Diabetic Patients with Post-Menopausal Breast Cancer. Genet. Mol. Res. 2016, 15. [CrossRef] [PubMed]

216. Ali Beg, M.M.; Verma, A.K.; Saleem, M.; Saud Alreshidi, F.; Alenazi, F.; Ahmad, H.; Joshi, P.C. Role and Significance of Circulating Biomarkers: MiRNA and E2F1 MRNA Expression and Their Association with Type-2 Diabetic Complications. Int. J. Endocrinol. 2020, 2020, 6279168. [CrossRef]

217. Rajkumar, K.V.; Lakshmanan, G.; Sekar, D. Identification of MiR-802-5p and Its Involvement in Type 2 Diabetes Mellitus. World J. Diabetes 2020, 11, 567-571. [CrossRef] [PubMed]

218. Zeinali, F.; Aghaei Zarch, S.M.; Vahidi Mehrjardi, M.Y.; Kalantar, S.M.; Jahan-Mihan, A.; Karimi-Nazari, E.; Fallahzadeh, H.; Hosseinzadeh-Shamsi-Anar, M.; Rahmanian, M.; Fazeli, M.R.; et al. Effects of Synbiotic Supplementation on Gut Microbiome, Serum Level of TNF- $\alpha$, and Expression of MicroRNA-126 and MicroRNA-146a in Patients with Type 2 Diabetes Mellitus: Study Protocol for a Double-Blind Controlled Randomized Clinical Trial. Trials 2020, 21, 324. [CrossRef] [PubMed] 